NBER WORKING PAPER SERIES

\title{
DID CRIMINAL ACTIVITY INCREASE DURING THE 1980s? COMPARISONS ACROSS DATA SOURCES
}

\author{
Scott Boggess \\ John Bound
}

Working Paper No. 4431

\author{
NATIONAL BUREAU OF ECONOMIC RESEARCH \\ 1050 Massachusetts Avenue \\ Cambridge, MA 02138 \\ August 1993
}

Direct all correspondence to John Bound, Population Studies Center, University of Michigan, 1225 South University Avenue, Ann Arbor, MI 48104-2590. We have benefited from extremely valuable and perceptive comments by Jeff Grogger on an earlier draft. We would also like to thank Jeff Miron for sharing his work in progress, and Carol Crawford and Cindy Glovinsky for manuscript preparation. Scott Boggess gratefully acknowledges support from NICHD training grant \#T32-HD07339. This paper is part of NBER's research program in Labor Studies. Any opinions expressed are those of the authors and not those of the National Bureau of Economic Research. 
NBER Working Paper \#4431

August 1993

\section{DID CRIMINAL ACTIVITY INCREASE DURING THE 1980s? COMPARISONS ACROSS DATA SOURCES}

\section{ABSTRACT}

There is a widely held belief that the level of serious criminal activity increased during the 1980s, particularly among the urban underclass. This increase has been mentioned as both a cause and consequence of the increasingly poor labor market prospects of less skilled workers. Significant increases in both Federal and State incarceration rates would seem to support this view. However, data from the Uniform Crime Reports (UCR) suggests only a mild increase in crime over this period, while the National Crime Survey (NCS) actually depicts lower levels of criminal activity. This paper carefully analyzes data from all three sources in an attempt to understand the nature of the series and to come to an informed opinion regarding the apparent differences in their trends. What we discover is that the large increase in the incarceration rate is attributable primarily to an increase in the likelihood of incarceration given arrest. During the latter part of the 1980s a dramatic increase in the number of arrests and incarcerations for drug law violations also played an important role. The increase in drug related activity was not registered by either the UCR or NCS because neither series measures the incidence of victimless crime.

Scott Boggess

Population Studies Center

The University of Michigan 1225 South University Avenue Ann Arbor, MI 48104-2590
John Bound

Population Studies Center

The University of Michigan

1225 South University Avenue

Ann Arbor, MI 48104-2590

and NBER 


\section{DID CRIMINAL ACTIVITY INCREASE DURING THE 1980s? COMPARISONS ACROSS DATA SOURCES}

It is commonly believed that there was a rise in the level of criminal activity during the 1980s, particularly among urban minority youth (Wilson 1987). Fueling these concerns have been reports that increasingly large fractions of young black men are, in one way or another, involved with the criminal justice system (in jail or on probation) (The Sentencing Project 1990; Bound and Freeman 1992; BJS 1992d; Langan 1991). It has been argued that the increased involvement with criminal activity has been both cause and consequence of the generally declining labor market prospects of less skilled workers, in particular less skilled black workers (Freeman 1991; Grogger 1992). The rapid increases in the fraction of the population in prison, which occurred during the 1980 s, would seem to support this view. However, the most frequently cited indicator of criminal activity, the Uniform Crime Reports' Crime Index (UCR), depicts only a moderate increase in criminal activity and National Crime Survey (NCS) victimization rates actually show some decreases in the rate of criminal activity (Jencks 1991). While the prison population increased by 126 percent from 1979 to 1989 , the UCR Crime Index increased by only 4 percent, and the NCS personal victimization rate actually decreased by nearly 27 percent.

In this paper we use available data to both explain the discrepancies between the three indicators of criminal activity and to come to an informed judgment regarding changes in the rate of criminal activity. The first section of this paper presents a brief description of the UCR and NCS and compares trends in the two measures. The next section seeks to explain the large increase in incarceration rates during the 1980s. This is followed by a close examination of recent trends in drug use and drug trafficking. The final section then presents some measures of the current level of criminal involvement by race. A reasonably consistent picture emerges. The statistics do not support the notion that there has been any overall rise in the level of criminal activity, but are consistent with the notion 
that the introduction of crack cocaine increased some types of criminal activity substantially.

The Uniform Crime Reports v. The National Crime Survey

The Uniform Crime Reports

Data for the UCR are collected monthly by the Federal Bureau of Investigation (FBI) from state and local law enforcement agencies. While participation is voluntary, reporting agencies currently cover over 95 percent of the U.S. population (FBI, 1992). The Uniform Crime Reporting Program, developed by the International Association of Chiefs of Police in 1929, collects information on all crimes except federal offenses and traffic violations. However, they only publish data on the number of offenses "known to the public" and their rate of occurrence for arson and a select number of crimes known as Index crimes. Index Crimes consist of murder and nonnegligent manslaughter, forcible rape, robbery, aggravated assault, burglary, larceny-theft, and motor vehicle theft, and include both attempted as well as completed incidents. For a crime to be included in the UCR, it must first be discovered and reported to the local police department or sheriff's office, they must then investigate the incident, agree that a crime has occurred, and file an official report of the incident.' In the case of rape, homicide, and aggravated assault one crime is counted for each victim, while for property crimes (robbery, burglary, larceny-tbeft, and motor vehicle theft) one crime is recorded for each incident regardless of the number of victims. ${ }^{2}$

The UCR Crime Index is probably the most frequently cited measure of the extent of crime in the United States. The Crime Index is an unweighted sum of the rate of occurrence of all seven Index offenses. It was designed to allow for the

1 In cases where a particular incident includes multiple offenses, only the most serious offense is reported. The above list ranks the UCR offenses from most to least serious. The exception is arson which is reported even if other more serious crimes have also occurred.

2 For example, if an individual were to break into a home and murder two of the occupants this would be counted as two homicides. If, on the other hand, the criminal broke into the house and removed possessions belonging to two different individuals this would only be recorded as one burglary. 
comparison of the level of serious crime from one time period to another and from one city or state to another. The above seven offenses were chosen as Index crimes because they represent serious crimes which are relatively likely to be reported to police and which can be consistently defined and recorded over time and across agencies.

How well the UCR measures trends in serious crime depends on the reporting behavior of individuals and the reconding behavior of law enforcement agencies. Not all crimes are reported to the police. In many cases the complaintant chooses to deal with the incident informally rather than through official means. The NCS collects extensive information on whether or not a particular incident was reported to police and, if not reported, the reasons for nonreporting. According to these surveys, reporting tends to be positively related to the seriousness of the crime (BJS 1992b).3 Reporting is also affected by the relationship between the victim and the offender. A crime is least likely to be reported if the victim and offender are related or the incident is commonly viewed as a personal or family problem, and most likely to be reported if the victim and offender are total strangers (BJS $1992 b)$.

The victim-offender relationship also tends to affect police recording behavior. Incidents where the victim and offender are related, or where the offender is young, are less likely to be recorded by the authorities (Block 1974; Black and Reiss 1970; Black 1970). Police recording practices will also tend to vary over time and across agencies. Agencies which are larger, more modern, or more professional will be more likely to record crimes (Skogan 1976). Differences in state and local laws, practices, and policies are also important determinants of how a crime is reported. In addition, the local political climate may influence recording. If a department is in need of funds or has recently received additional funds there is likely to be an increase in the recording of criminal incidents to demonstrate the need for or justify the receipt of these funds (Chambliss 1984). Likewise, a declared intention

\footnotetext{
${ }^{3}$ The BJS estimates that approximately 79 percent of robberies with serious assault are reported to the police, while fewer than 14 percent of larcenies less than $\$ 50$ are reported (BJS 1992b).
} 
to target certain types of crime should be expected to increase the number of such crimes recorded.

\section{The National Crime Survey}

The National Crime Survey originated in 1973 and is administered by the Bureau of the Census for the U.S. Department of Justice, Bureau of Justice Statistics. As originally envisioned, the NCS was supposed to capture all crimes known to police as well as many crimes that were either not reported or recorded. While it was recognized that the victimization surveys would not be able to estimate all crimes that actually occurred, it was generally believed that they would provide a more complete picture of the level and trend of serious criminal activity than the UCR.

The NCS surveys a representative sample of approximately 50,000 addresses containing roughly 100,000 individuals age 12 and older. Each address is surveyed every 6 months for 3 years, comprising a total of seven surveys. The NCS questionnaire gathers information on the crimes of rape, robbery, assault (aggravated and simple), personal larceny, burglary, household larceny, and motor vehicle theft, both completed and attempted. Like the UCR, the NCS counts each criminal incident only once by the most severe offense that occurred during the incident. In addition to information on the number of victimizations, the NCS collects detailed information about the victim, the incident, and the perceived characteristics of the offender(s).

There are two primary parts to the questionnaire. The first section collects general information on the household and asks a set of household and individual screening questions designed to discover whether anyone in the household was victimized within the last 6 months. The second section of the questionnaire, administered only if the screening questions indicate that a victimization likely occurred, consists of crime incident reports designed to obtain detailed information 
on these victimizations. The individual level questions are asked of all household members age 12 and over.

The NCS publishes two aggregate crime measures: the personal victimization rate; composed of the crimes of rape, robbery, assault, and personal larceny; and the household victimization rate; composed of burglary, household larceny, and motor vehicle theft. The personal victimization rate is measured per population age 12 and older while the household victimization rate is measured per 1,000 households. Like the UCR Crime Index, these measures are designed to provide a picture of the overall trend in criminal activity from one year to another.

As mentioned above, the NCS, like the UCR, is unable to accurately estimate all serious criminal activity. Both surveys have a difficult time measuring attempted crimes, since respondents often fail to realize that a crime attempt has occurred. This is especially true for the crimes of burglary and household larceny where there is no direct contact between the victim and offender. In addition, respondents may not define an attempted crime as a crime, especially if there is no property loss. Household victimizations, especially larcenies, are further underreported because the household screening questions are asked of only one individual at each address (Biderman and Lynch 1991). There is also the problem that victims often fail to recall the crime accurately. The issue of recall seems to be most serious for assaultive crimes, where the victim and offender are frequently nonstrangers. For example, if the respondent has been repeatedly victimized in a similar manner over the last 6 months (i.e., domestic violence) they may be unable to recall specific details of each incident. In these instances, known as series victimizations, the NCS interviewer completes one incident report, containing detailed information on only the most recent victimization. Because they cannot

1 Proxy responses from knowledgeable adults are accepted for family members who are unable to respond at the time of the interview.

5 According to the Bureau of Justice Statistics (BJS), "recall problems may result in a substantial understatement of the actual rate of assault" (BJS 1992b). A cross check of police records on assaults found that, of assaults recorded by the police, 76.3 percent of assaults by a stranger were reported to the NCS interviewer, 56.9 percent of assaults by a nonstranger and only 22.2 percent of assaults by relative (Turner 1972). 
be dated to a specific month, series crimes are not included in NCS incidence and victimization rates thus leading to an underestimation of some types of crime.

The NCS is based on a national stratified multistage cluster sample of addresses, not households. Like other surveys conducted by the Census, the NCS tends to underrepresent "hard-to-find" groups, such as young black men and nonenglish speakers, who are more likely to be victimized than other demographic groups (Block and Block 1984). This too will cause the NCS to underestimate the level of criminal activity.

There is also evidence to suggest that, in some cases, respondents knowingly misreport the number of criminal incidents. In a 1976 article, Levine suggests that respondents may report crimes to the NCS interviewer that never occurred or that occurred to someone outside of their own household in an attempt to dramatize the crime issue or give the interviewer what they believe they are looking for (Levine 1976). In addition, they may fail to report victimizations that actually occurred for fear of prolonging the interview process, this is more likely to be an issue for respondents who reported a victimization in previous interviews (Block and Block 1984).

\section{Comparisons of Trends}

Figure 1 presents the UCR Crime Index, the NCS personal victimization rate, and the NCS household victimization rate for 1973-1991. Although the three series appear to be converging, they depict quite different trends in crime over this period. According to the UCR Crime Index, serious crime has increased by 42 percent since 1973 while, over the same period, the NCS personal victimization rate decreased by 25 percent and the NCS household victimization rate fell by 26 percent. If we focus on the period since 1979, we find that the UCR Crime Index increased by 7 percent while the NCS personal and household victimization rates decreased by 27 and 31 percent respectively.

\section{Figure 1 About Here}


While both the UCR Crime Index and the NCS estimates are designed to measure the general trend in criminal activity they do possess some significant differences. Unlike the UCR, the NCS, for obvious reasons, does not collect information on commercial crimes or on the crimes of murder and nonnegligent manslaughter. ${ }^{\circ}$ On the other hand, the NCS records the incidence of both simple and aggravated assault while the UCR considers only the latter. In addition, the UCR measures crime occurring to the entire population while the NCS sample is restricted to those 12 and older. Although, because there are not likely to be a significant number of younger victims, and because crimes to those under 12 usually go unreported (O'Brien 1985), this probably has little effect on the numerator of the NCS rates. It is true, however, that during the 1970s and early 1980s the total population grew at a slower rate than either the population 12 and older or the population of households, thus causing the NCS victimization rates to decrease relative to the UCR Crime Index (Blumstein et al. 1991). Another problem with comparing these series is that the NCS measures victimizations on both an individual and household level while the UCR data are all individual level measures.

In an attempt to make the NCS and UCR data more comparable, we omitted homicide from the Crime Index and simple assault from the NCS estimates. We also, when possible, subtracted commercial crimes from the UCR numbers (e.g., nonresidential burglary, shoplifting, and thefts from coin operated machines). We then combined the estimated number of personal and household victimizations and expressed them per 100,000 total population. Figure 2 presents the new or adjusted UCR Crime Index and NCS victimization rate. Again we notice, even after these adjustments, that the two series appear to depict very different trends in serious criminal activity from 1973 to 1991 . The adjusted victimization rate decreases by 21.2 percent from 1973 to 1991 , an annual rate of decrease of 1.3 percent, and 27.1 percent from its peak in 1979 to 1991 , somewhat less than the

\footnotetext{
${ }^{6}$ Commercial crimes comprise approximately one-third of all UCR burglaries and larcenies, 10 percent of motor vehicle thefts, and an unknown number of robberies (FBI 1992; Biderman and Lynch 1991; O'Brien 1985).
} 
decreases observed in the unadjusted series in Figure 1. The adjusted UCR crime rate increased by 44.9 percent since 1973 , an annual rate of increase of 2.0 percent, and 6.4 percent since 1979, changes slightly larger than those observed in Figure 1. Thus, these adjustments explain little of the difference in trends between the two series.

\section{Figure 2 About Here}

There is evidence, however, that part of the difference in trends is due to increased reporting of victimizations to the police. As part of the NCS crime incident report each victim is asked whether or not they reported the incident to the police. According to the BJS, the percentage of victimizations reported to the police increased from 32 percent in 1973 to 38 percent in 1991 (BJS 1992c), an increase of 19 percent. Relative to the NCS, the UCR actually rose by roughly 75 percent. Thus increases in the fraction of crimes reported to the police would seem to account for roughly one-quarter of the discrepency between the UCR and the NCS.

The discussion above suggests that the quality of reporting should vary across offenses. For this reason it is if some interest to compare the UCR and NCS by type of offense. UCR and NCS trends in each of the six common offenses-rape, robbery, aggravated assault, burglary, larceny-theft, and motor vehicle theftappear in Figure 3. As Figure 3 illustrates, the UCR and NCS trends for robbery, burglary, and motor vehicle theft are relatively similar while those for rape, aggravated assault, and larceny are quite different. Among the common violent crimes, robbery is probably the most accurately measured. Robbery is likely to be well reported both to police and to NCS interviewers not only because it is a serious offense but also because the offender is usually a stranger and rarely a relative (over 80 percent of robberies reported to NCS interviewers were committed by strangers (BJS 1992b)). However, in the case of rape and aggravated assault (the unlawful attack of another, usually involving a weapon, resulting in severe bodily injury) the offender is often a nonstranger (two-thirds of completed rapes and 45 
percent of aggravated assaults with injury involve nonstrangers (BJS 1992b)) and, as a result, these crimes are probably not measured well by either the UCR or NCS. Among nonviolent crimes, larceny is the least likely to be reported to the police. This is due primarily to the fact that larceny is the least serious of all Index offenses. The NCS estimates that only about one-quarter to one-third of all larceny victimizations are ever reported (BJS 1992b).

\section{Figure 3 About Here}

According to the NCS the type of victimization most likely to be reported to the police is motor vehicle theft. In 1990, NCS respondents reported that a full 75 percent of motor vehicle theft victimizations were brought to the attention of the police (BJS 1992b). Motor vehicle theft is so well reported because an individual's automobile is often one of their most valuable possessions, because it is difficult to conceal the theft for any significant period of time, and because victims are often required to report the theft to police in order to obtain a settlement from their insurance company. Figure 3 clearly shows that the overall trends for motor vehicle theft are more similar than those for the other common offenses.

To summarize, the Uniform Crime Reports' Crime Index depicts a different trend in the level of serious criminal activity than either the National Crime Survey personal victimization rate or the NCS household victimization rate. Adjusting for the types of crime measured and the population base of the two series explains very little of this difference. However, when we decompose the indices into their six common offenses and adjust for measurement differences, we find that it is primarily for those crimes that are known to be poorly measured both by the UCR and NCS; rape, aggravated assault, and larceny; that the trends are significantly different. For those offenses which are measured more accurately; robbery, burglary, and motor vehicle theft; the two data series are much more comparable.

We are, however, still left with large differences in trends for rape, aggravated assault, and larceny. We find it easier to believe that these differences reflect a 
combination of an increase in the fraction of crimes reported to the police and in the fraction of reported crimes that are formally recorded than any drop in the fraction of crimes reported to NCS interviewers. We have seen evidence that the fraction of crimes reported to the police rose over the last two decades. While we have no hard evidence of any changes in the recording behavior of the police, we do know of forces that could have worked in that direction. As was noted above, modernization itself seems to increase reporting rates. We can also imagine that the significant increases in the likelihood of incarceration given arrest (see Incarceration Rates section), could have encouraged police to file formal reports of these incidents (Jencks 1991; Blumstein et al. 1992).

It is possible to use the NCS to estimate the number of crimes reported to the police. Overall, the ratio of the number of crimes recorded in the UCR to the estimated number of crimes reported to the police rose from roughly 0.6 in 1973 to 1.0 by the end of the $1980 \mathrm{~s}$. These numbers are consistent with the notion that what accounts for the discrepency in trends between the NCS and UCR is changes in the fraction of crimes reported to the police that are recorded (Jencks 1991; Blumstein et al. 1992). ${ }^{7}$ By implication, trends in the NCS and UCR should be converging. There does seem to be some evidence that this is, in fact, occurring. Figures 2 and 3 suggest that the discrepancy in terms of trends between the NCS and UCR was more dramatic during the 1970s than during the 1980s. However, the time series available are simply too short to allow for any clear resolution of this issue (McDowall and Loftin, 1992).

\section{Victimization Rates by Race}

The NCS also presents much of its victimization data by race. This data is of interest because the aggregate crime trends may be masking different racial trends in criminal involvement. Figures 4 and 5 depict selected NCS victimization rates by race of the victim and the perceived race of the offender respectively. Since

\footnotetext{
7 For some crimes, most notably rape, by the end of the 1980s the number of crimes recorded by the police actually exceeds by nontrivial margin the number the NCS implies was reported to the police (Blumstein et al. 1992). This is consistent with the notion that such crimes are underreported in the NCS.
} 
approximately 72 percent of all violent crimes against whites are committed by whites and roughly 84 percent of all violent crimes against blacks are committed by blacks (BJS 1992b), we can be relatively safe in assuming that trends in black and white victimizations roughly approximate trends in black and white crime. It should be noted that the black estimates will possess greater variability than the white estimates due to the smaller sample size. Looking at victimizations by race of the victim, Figures 4a-4f, we find that, for most offense categories, the black rates and the white rates follow highly similar trends. The one exception to this general rule is auto thefts. Here we see some evidence that during the late 1980 s the victimization rate went up more rapidly for blacks than for whites.

\section{Figure 4 About Here}

The NCS asks victims of both robbery and aggravated assault to identify the probable race of their assailant; over 95 percent of victims do manage to identify the race of their assailant (BJS 1992c). Figure 5 shows robbery and aggravated assault rates by race of offender. ${ }^{8}$ Both races exhibit similar trends in involvement. From 1980 to 1991 the black robbery rate decreased by 3 percent while the white robbery rate decreased 23 percent. Over this same period the black and white aggravated assault rates decreased by approximately 10 and 15 percent respectively.

\section{Figure 5 About Here}

\section{Murder}

Arguably the most reliable indicator of the overall trend in violent crime is the UCR murder rate. Because murder is the most serious of the Index offenses and because it is difficult to conceal from authorities, it is both well reported and well recorded. In addition, there is no reason to believe that there have been changes in either reporting or recording behavior over the last 20 years. Figure 6

\footnotetext{
These figures include only those crimes with a single victim and single offender. In 1991 , approximately 50 percent of robberies and 66 percent of aggravated assaults were single victim/single offender incidents (BJS 1992c).
} 
presents the overall UCR murder rate and the murder rate by race of offender for single victim/single offender murders from 1976 to $1991 .^{\circ}$ According to the figure, the overall murder rate decreased somewhat over the 1980s from 10.2 per 100,000 in 1980 to 9.8 per 100,000 in 1989. Figure 6 also depicts significant declines in both the black and white murder rates during the 1980s. The black murder rate decreased 25 percent, from 24.6 to 18.5 per 100,000 , and the white rate decreased by 24 percent from 3.1 to 2.3 per 100,000 .

\section{Figure 6 About Here}

UCR murder data is also available by the race and age of the victim. In Figure 7 we report rates for selected age groups. Here we observe that the murder rates for youth and young adults are substantially higher than those for the rest of the population. It should be noted that the rates for young blacks are inflated by the census undercount of blacks, though the magnitude of the undercount should have remained constant through the $1980 \mathrm{~s}$. Also of note is the fact that, unlike the other demographic groups, the murder rate for both white and black youth began to increase during the latter half of the 1980s. This break in trend is particularly stark for black youth.

\section{Figure 7 About Here}

\section{Summary}

Has criminal activity increased during the 1980s? Data from the FBI and BJS seem to indicate no general increase in the overall level of criminal activity. Evidence from the UCR murder rate and the UCR and NCS robbery rates suggests that there was a 20-30 percent decrease in the level of violent crime in the early 1980 s, followed by a 10-20 percent increase in the late 1980s and early 1990s. Furthermore, after peaking in the early 1980s household crime (burglary and larceny) appears to have decreased through the end of the decade. When we analyze the

\footnotetext{
${ }^{9}$ Single victim/single offender murders account for just over 50 percent of all murders. In 99 percent of these murders the race of the offender is available from police records (FBI 1992). This data was first published in $\mathbf{1 9 7 6 .}$
} 
data separately by race we discover that, in almost all offense categories, the level of criminal involvement among both whites and blacks has actually decreased. There is, however, some evidence that, over the late $1980 \mathrm{~s}$, involvement in violent crime (e.g., murder) has increased among both black and white youth.

\section{Incarceration Rates}

Given that there appears to have been no significant upward trend in criminal activity during the 1980s, what accounts for the large increase in the incarceration rate over this period? Obviously not all victimizations result in the incarceration of the perpetrator(s). In order for there to be an incarceration the victimization must first be reported to authorities; the police must file a report of the incident and arrest a suspect(s); the suspect(s) must then be tried, found guilty, and sentenced to prison. Thus it is possible that the large increase in the incarceration rate is due to an increase in either the percentage of victimizations reported to police, the number of arrests per crime, the number of convictions per arrest, or the number of prison sentences per conviction. It could also be the case that the average sentence length has increased and prisoners are, on average, spending an increasingly longer time in prison. This would occur if there has been an increase in the average sentence length for each type of offense or if those sentenced to prison are increasingly likely to be very serious offenders who generally tend to draw longer sentences. Another possibility is that there has been a large increase in serious victimless crimes, such as drug law violations, which are likely to draw prison sentences but which are not represented in the UCR crime and NCS victimization numbers reported above.

The incarceration rate measures the number of prisoners under jurisdiction of Federal and/or State authorities at the end of the year. By restricting the measure to those sentenced to maximum terms of more than 1 year we ensure that we are dealing primarily with felons and not misdemeanants. The incarceration rates show an accelerating trend over the 1970s and 1980s. Between 1970 and 1980 the fraction of the population incarcerated for felonies rose 39 percent from 1 per 
thousand to 1.39 per thousand while during the $1980 \mathrm{~s}$ it increased by 112 percent, from 1.39 to 2.95 per thousand population, a rate of increase roughly triple that of the 1970s. Since the State Prison population is more than 10 times the size of the federal prison population, this dramatic rise is dominated by the rise in the number of inmates in state facilities. ${ }^{10}$

In an attempt to help determine which of the above factors was responsible for the dramatic increase in incarceration rates during the 1980 s we decomposed the annual rate of change in new court commitments to state prisons, measured in log points, into the sum of the share of each offense in total commitments times the annual rate of change in the rate of new court commitments for that offense. ${ }^{11}$ We have

$$
d \ln (I)=\sum_{i} S_{i} d \ln \left(I_{i}\right)
$$

where $d \ln (I)$ represents the annual rate of growth in new court commitments, $d \ln \left(I_{i}\right)$ represents the annual rate of growth in new commitments for offense $i$, and $S_{i}$ represents new commitments for offense $i$ as a share of total new commitments $\left(S_{i}=\frac{t_{i}}{t}\right) .^{12}$

We further decomposed the annual rate of change in new court commitments for each offense into the sum of the annual rate of change in arrests and the probability of incarceration given arrest, both measured in log points (equation 2).

$$
\sum_{i} S_{i} d \ln \left(I_{i}\right)=\sum_{i} S_{i} d \ln \left(A_{i}\right)+\sum_{i} S_{i} d \ln \left(P_{i}\right)
$$

\footnotetext{
10 In fact, both the federal and state incarceration rates doubled during the $1980 \mathrm{~s}$.

11 The number of new court commitments was obtained by multiplying the total number of new commitments by the offense distribution for that year. In 1974 and 1979 the total number of new commitments was unavailable and was estimated from the number of state
prison admissions in those years and the percentage of admisoions which were new court commitments in 1985 (the firet year for which this information was available).

12 This equation was derived as follows: $\sum_{i} s_{i} d \ln \left(I_{i}\right)=\sum_{i} f \frac{U_{i}}{U_{i}}=t \sum_{i} d I_{i} f d I=d \ln (I)$.
} 
Where $d \ln \left(A_{i}\right)$ represents the annual rate of change in arrests for offense $i$, and $d \ln \left(P_{i}\right)$ represents the annual rate of change in the probability of incarceration given arrest for offense $i^{13}$

To implement the decomposition, we classified offenses into one of eight categories: homicide (murder, nonnegligent manslaughter, and negligent manslaughter), rape and other sexual assault, robbery, assault, burglary, larceny and motor vehicle theft, drug law violations, and all other offenses. We perform this decomposition for state prisons over the periods: 1974-1979, 1979-1988, and 1974-1988. For the shares $\left(S_{i}\right.$ 's) we used shares averaged over the beginning and end periods. ${ }^{14}$ To net out population growth we expressed both incarcerations and arrests as fractions of the total population. The results of the decomposition appear in Table 1.

\section{Table 1 About Here}

From 1974 to 1979 the annual rate of increase in new commitments $\left(\sum_{i} S_{i} d l n\left(I_{i}\right)\right)$ was 4.6 percent, the result of a 5.2 percent increase in the annual probability of incarceration conditional on arrest coupled with a .6 percent decrease in the overall annual arrest rate. Of the eight offenses, robbery and burglary combined accounted for approximately 43 percent of this change $(.009+.011 / .046)$, due largely. to the fact that they represent the largest shares of new commitments, 20 and 24 percent respectively. Looking at columns 2 and 3 we find that the increase in robbery and burglary commitments is due solely to an increase in the probability of incarceration, the likelihood of arrest actually decreased for both offenses. The largest annual rate of increase in new commitments occurs for "other" offenses and is responsible for approximately 30 percent of the total annual rate of increase. Although there was an increase in the probability of arrest for "other" offenses, the increase in new commitments is largely attributable to an 8.7 percent increase

13 Since $\sum_{i} S_{i} \ln \left(\Lambda_{i}\right)$ and $\sum S_{i} \ln \left(P_{i}\right)$ represent the change in the arrest and incarceration rates weighted by their relative share in incarcerations, they will not equal the aggregate change in arrests or incarcerations.

14 While in continuous time equation (1) is an identity, it will only approximately hold in discrete time. 
in the annual probability of incarceration given arrest. Interestingly enough we observe that new commitments for drug offenses actually decreased during this period due to a significant decrease in the annual rate of change in the arrest rate for drug law violations.

For the later period, from 1979 to 1988, new court commitments rose at an annual rate of 8.9 percent. Of this increase, a majority was the due to a higher probability of incarceration (.074/.089). Incarceration for drug related offenses was becoming increasingly important over this period. The proportion of new commitments entering state prisons for drug offenses increased from 8 to 25 percent, due to both to a $\mathbf{2 . 4}$ percent increase in the annual incarceration rate and a 1.2 percent increase in the annual arrest rate for drug law violations. In fact, drug offenses accounted for a full 40 percent of the rise in the prison population between 1979 and 1988 .

The data in Table 1 refer to new commitments. However, the ratio of new commitments to the prison population hardly changed over this period of time, indicating that there was little change in the effective sentence length. Additional data from inmate surveys of State prisons and surveys of State courts confirm that, during the 1980s, median State prison sentences and median time served bave remained constant or decreased for most offenses (Langan 1991; BJS 1990d; 1992c). Information on Federal sentences during the 1970s and early 1980s also confirms that there has been almost no change in average sentence length or time served for Federal prisoners from 1980 to 1986.

To summarize, the large increase in the incarceration rate in the 1980 s seems primarily attributable to two overlaping factors. Most importantly there was an increase in the probability of incarceration conditional on arrest for all offense categories. Also contributing to the increase was a large increase in the number of new commitments for drug law violations. Together, these two factors accounted for over 95 percent of the increase in new court commitments during the $1980 \mathrm{~s}$. 


\section{Drug Use and Drug Law Violations}

As mentioned above, one of the factors responsible for the large increase in the incarceration rates during the $1980 \mathrm{~s}$ was an increase in the incarceration rate for drug law violations. This section takes a closer look at trends in drug use and drug violations over the last decade. Figure 8 presents trends in the arrest rates for Index crimes and drug crimes for the period from 1970 to 1991 . While drug arrests are only a fraction of total arrests they represent an increasingly important part of arrests for serious crimes. From 1980 to 1989 the drug arrest rate increased by over 111 percent, from .26 per 1,000 to .55 per 1,000 , before decreasing in the early 1990s. During this same period the arrest rate for Index crimes increased by only 19 percent.

\section{Figure 8 About Here}

There are a number of possible explanations for the recent increase in drug arrests. It could be that there has been a large increase in drug use over the last 10 years and that the higher arrest rates are the result of a larger population being engaged in the sale, manufacture, and possession of serious drugs. Another possibility is that, while the number of individuals involved in drug activity has not changed very much, the country's declared "war on drugs" has resulted in an increase in the amount of resources devoted to the capture and prosecution of both drug dealers and drug users. Since most of the increase in drug arrests and incarcerations has been linked to cocaine we will focus our attention on trends in cocaine use among various segments of the population. ${ }^{15}$

Two of the most prominent surveys that ask about drug use are Monitoring the Future: A Continuing Study of the Lifestyles and Values of Youth (MTF) and the National Household Survey on Drug Abuse (NHSDA). Both MTF and NHSDA are sponsored by the National Institute on Drug Abuse (NIDA). MTF began in 1975

\footnotetext{
15 According to the FBI, the arrest rate for the sale and/or manufacture of cocaine or heroin increased from 10.8 per 100,000 population in 1980 to 100.6 per 100,000 in 1989 , an increase of 831 percent. Over this same time period the arrest rate for cocaine or heroin possession increased by 723 percent, from 22.2 to 182.8 per 100,000 (FBI 1981; 1990).
} 
as an annual survey of high school seniors. Since 1975 MTF has not only collected information on each subsequent class of seniors but also resurveyed a subsample of each previous cohort. An important limitation of the MTF survey is that it does not include the 15-20 percent of each cohort that drop out of school before their senior year. The NHSDA is an occasional survey, which collects information on the prevalence of drug, alcohol, and tobacco use for those age 12 and older. The NHSDA sample is drawn from a national probability sample of households.

Figures 9 and 10 present trends in recent cocaine use by age from MTF and the NHSDA respectively. According to Figure 9, cocaine use among all age groups was relatively constant through the mid 1980s but decreased dramatically after 1986 . Disaggregating by race shows similar trends for black and white youth, though the fraction of blacks reporting the use of cocaine is roughly half that of whites (Backman et al. 1991). In addition, Backman et al. (1990) present evidence that the decline in cocaine use that occurred during the 1980 s can largely be attributed to changes in the perception of the dangers associated with use.

\section{Figure 9 About Here}

Trends in cocaine use from the NHSDA (Figure 10) depict increasing cocaine use during the 1970s for all three age groups. Cocaine use among those 12 to 25 years old appeared to peak around 1979 and decrease throughout the 1980s, while cocaine use among older adults continued to rise through 1985 before finally tapering off.

\section{Figure 10 About Here}

Neither MTF nor NHSDA are intended to measure the prevalence of drug dependence or drug abuse. The one survey designed to measure such use, the Epidemilogic Catchment Area study (ECA), done in the early 1980s, shows rates of drug abuse that are dramatically lower than the rates of drug use shown in 
MTF or NHSDA (Anthony and Helzer 1991; Kandel 1992).16 Given this large discrepancy it would seem entirely possible that trends in drug use would not necessarily follow trends in drug abuse.

Reliable data on serious drug use is relatively difficult to find. One possible measure of the level of serious cocaine use is the number of individuals treated in hospital emergency rooms for cocaine related problems. NIDA, through the Drug Abuse Warning Network (DAWN), collects annual information on the number of drug related emergency room visits in 21 selected metropolitan areas. While the number of emergency rooms and the size and composition of the population they serve varies somewhat from year to year, these surveys provide us with an alternative measure of drug use. According to Figure 11, cocaine admissions to emergency rooms rose dramatically starting in the mid 1980s. Figure 11 also shows that the bulk of this increase was accounted for by individuals identified as having smoked rather than sniffed the cocaine, a clear indication that a large fraction of the increase in emergency room use was due to the introduction of crack cocaine.

\section{Figure 11 About Here}

The DAWN surveys also reveal some interesting trends in the demographic characteristics of patients with cocaine related emergencies. Two-thirds of all patients were male, a figure that remained fairly constant during the 1980s. The percentage of black and Hispanic patients, however, increased steadily from 45.8 percent in 1981 to 66.6 percent in $1989 .{ }^{17}$ There was also a change in the age composition of patients. In 1989, 20 to 29 year olds comprised 45.9 percent of patients, down from 55.1 percent in 1981. This increase was largely offset by an increase in the percentage of 30 to 49 year olds. In addition to the changes in

16 The fraction of the population shown as abusing cocaine in the ECA data was 0.2 percent. In comparison, the NHSDA data show 18.8 percent of young adults and 3.8 percent of older adults using cocaine in 1982.

17 It is interesting to note that while blacks are under-represented among cocaine users, they are over-represented in the DAWN surveys. This discrepancy may, to some extent, reflect differences in patterns of emergency room use. There is, however, some evidence suggesting that, while blacks are less likely to initiate the use of cocaine, they are more likely to continue to use the substance after initiation (Kandel 1991). 
demographic composition of patients there was also a change in their drug use motives. The percentage of patients reporting that they used cocaine because of dependence increased from 48.4 percent in 1981 to 63.2 percent in 1989 , while those reporting that they used cocaine for its psychic effects decreased from 33 percent to 19.6 percent. ${ }^{18}$ These findings tend to support the belief that there was a cocaine/crack epidemic in the mid 1980s. In the early 1980s, as cocaine became more accessible and new forms of cocaine became available, the majority of users where taking the drug for recreational purposes or out of curiosity but over time, as individuals became more aware of the dangers of cocaine use, the number of new users decreased and a larger and larger fraction of those who were able to quit did so. The result was an increase in both the average age of users and the percentage of those using because of dependence.

Recent trends in cocaine death rates and drug dependence death rates also support the notion that serious or heavy cocaine use increased during the 1980s. The death rate for blacks and whites from cocaine remained essentially zero through the mid 1980s and then began to rise rapidly around 1984. Between 1984 and 1988 , the cocaine related death rate for black males increased by 1,667 percent, from .15 to 2.65 per 100,000 , while the death rate for whites increased only 257 percent, from .14 to .50 per 100,000 .

The DAWN data and Vital Statistics information on cause of death are both susceptible to systematic reporting biases. As medical professionals become more familiar with the symptoms of serious drug and cocaine use they are more likely to report emergency room visits and deaths as drug/cocaine related. However, both the timing of the increase in emergency room use and the increase in deaths are consistent with what is known regarding the timing of the introduction of crack. After being introduced in Los Angeles around 1982, crack spread rapidly to other major U.S. cities and was available nationwide by 1986 (Lamar 1986; Morganthau et al. 1986).

\footnotetext{
${ }^{18}$ In those instances where more than one drug was mentioned the same motive for use was
} assigned to all drugs involved. 
However, it is important to note that crack cocaine is significantly more toxic than other forms of cocaine. Thus, the increases in emergency room use and in cocaine related deaths could be due either to an increase in the serious use of cocaine or simply to a substitution of more toxic crack for less toxic forms of cocaine (or other drugs). We suspect that, in reality, it was a combination of the two phenomena. The introduction of crack cocaine dramatically reduced the price of cocaine making it available to a much wider spectrum of individuals, likely leading to both an increase in the total demand for cocaine and a shift of this demand towards crack.

An indicator of the level of serious drug trafficking is the number of drug related murders. Data on the total number of murders and drug related murders from 1976 to 1991 appears in Figure 12. The percentage of total murders which were drug related remained constant at just below 2 percent from 1976 to 1982. From 1982 to 1989 , however, drug related murders increased from 2 to 7.4 percent of all murders. Furthermore, the increase in the number of drug related murders during this period was more than three times as large as the increase in total murders. While there is good reason to be suspicious that these numbers, to some extent, reflect reporting behavior by the police, the overall murder rate among young adults follows exactly the same type of pattern.

\section{Figure 12 About Here}

In sum, although it is difficult to determine the magnitude of drug use or the drug trade, the fact that all the above series follow the same pattern makes it seem fairly incontrovertible that drug traffic and serious drug use were increasing in the late 1980s. The break in trend that occurred in the mid 1980s would seem to implicate crack. Plausibly, the introduction of crack cocaine expanded the market for cocaine and thereby increased the value of the drug trade. The violence associated with the drug trade increased due to the completely unregulated (i.e., illegal) nature of the market. This interpretation of the evidence is consistent with survey evidence which suggests that youth perceive crime to be more lucrative 
today than they did a decade ago (Freeman 1991). It is also consistent with recent ethnographic evidence that shows gangs during the 1980s putting an increased emphasis on money making through the sale of cocaine (Freeman 1992; Huff 1990; Sullivan 1989; Williams 1989).

Recent Estimates of the Level of Involvement in Criminal Activity and Drug Use

While most of this paper has focused on recent trends in criminal involvement, the final section of the paper examines various measures of the level of crime and drug activity by race and age. Given that drug/cocaine related activity has increased rapidly during the 1980s, how does the current level of drug/cocaine involvement compare with involvement in other types of crime? Table 2 presents recent victimization rates, murder rates, arrest rates, incarceration rates, emergency room cocaine admission rates, and cocaine death rates for various demographic groups.

\section{Table 2 About Here}

Our two measures of the level of drug crime are the 1990 drug arrest rate and the 1988 drug incarceration rate. In 1990, the arrest rate for drug law violations was 2.52 per 1,000 for whites and 11.67 per 1,000 for blacks. These rates are greater than the arrest rates for violent crime and motor vehicle theft combined and account for over 25 percent of all arrests for serious crimes (Index crimes and drug offenses). When we consider that the majority of those arrested for serious crimes are young males and that arrests for serious crimes generally constitute less than 15 percent of all arrests, we find that the actual level of criminal involvement for young men, especially young black men, is significantly higher.

If we compare the drug arrest rates to recent victimization rates we find that blacks are more than three times as likely to be victims of violent crime (rape, robbery, and assault) and more than five times as likely to be victims of theft than they are to be arrested for a drug offense. Whites, on the other hand, are 
11 times as likely to be victims of violent crime and more than 25 times as likely to be victims of theft than they are to be arrested for a drug law violation. ${ }^{19}$

Because a large fraction of those arrested are never sentenced to prison it should not be surprising to find that incarceration rates are much smaller than arrest rates. In 1988, the drug offense incarceration rate was .09 per 1,000 for whites and .89 per 1,000 for blacks. These rates are roughly comparable to the total violent crime incarceration rates and are approximately 10 times as large as the incarceration rates for murder and motor vehicle theft. Of all individuals incarcerated for serious crimes, approximately 28 percent of whites and 34 percent of blacks were incarcerated for drug law violations..$^{20}$ Comparing these numbers to recent murder rates we find that, in a given year, whites and blacks are roughly twice as likely to be incarcerated for drugs as they are to be murdered. This comparison is, however, somewhat misleading as an individual may be incarcerated multiple times while he/she can only be murdered once. In sum, while drug crime appears to represent a significant share of total criminal activity, the level of serious criminal involvement with drugs, as measured by the drug incarceration rate, is relatively small-fewer than one in 10,000 whites and one in 1,000 blacks were incarcerated for drug law violations in 1990.

How do our measures of serious criminal involvement with drugs/cocaine compare with our measures of serious drug/cocaine use? According to the final sections of Table 2, the likelihood of being treated in an emergency room for a cocaine related emergency is slightly greater than the probability of being incarcerated for a drug offense and roughly three times as large as the single-year murder rate. However, as with arrests and victimizations, many of those seen for cocaine related emergencies are likely to be treated more than once in a particular year. Cocaine death rates are clearly the smallest of the rates in Table 2. They indicate that

\footnotetext{
10 Because an individual may be arrested or victimized more than once in a particular year, the above rates will all tend to overestimate the actual level of criminal activity.

20 In the section on Incarceration Rates we noted that 25 percent of individuals incarcerated for all felonies were incarcerated for drug law violations. Serious crimes include all felonies except kidnapping, negligent manslaughter, "other violent" crimes, fraud, public order offenses, and "other" offenses.
} 
fewer than one in 3 million whites and one in 625,000 blacks died from cocaine related causes in 1988 . These numbers are likely to be underestimates as many drug related deaths are attributed to other causes (e.g., cardiac arrest).

Evidence from Table 2 also seems to suggest that blacks have borne a disproportionate share of the costs of increased drug use and drug trafficking. While the violent crime and personal theft victimization rates are roughly comparable for blacks and whites; the drug arrest rates, incarceration rates, ER admission rates, and cocaine death rates are 5 to 12 times as large for blacks as they are for whites.

\section{Discussion}

This paper employs data from the UCR and NCS to examine the widely held belief that there was a significant increase in the level of criminal activity during the 1980s. In general, we find that neither data source depicts increasing levels of crime over this period. The only exceptions seem to be murders among young adults and motor vehicle theft both of which exhibit significant upward trends in the mid to late 1980 s. While the level of criminal activity remained relatively stable during the 1980s, there was a large increase in the incarceration rate, primarily attributable to an increased probability of incarceration given arrest for all offense categories and a sizable increase in the number of arrests and incarcerations for drug law violations.

Data on cocaine related emergency room visits, drug deaths, and drug related murders suggests that the increase in the number of incarcerations for drug offenses is the result not only of increased enforcement of existing drug laws but also of a significant increase in the use and sale of crack cocaine. This increase does not appear in either the UCR or the NCS numbers because neither data source measures the incidence of victimless crime. The spread of crack through the central cities of the U.S. seems reminiscent of the spread of heroin a generation earlier (Clark 1965; HARYOU 1964). 


\section{REFERENCES}

Anthony, J. C. and J. E. Helzer. 1991. "Syndromes of Drug Abuse and Dependence." Pp. 116-154 in L. Robins and D. Reiger (eds.), Psychiatric Disorders in America. New York: Free Press.

Bachman, Jerald G., L. D. Johnston, and P. M. O'Malley. 1990. "Explaining the Recent Decline in Cocaine Use among Young Adults: Further Evidence That Perceived Risks and Disapproval Lead to Reduced Drug Use, ${ }^{n}$ Journal of Health and Social Behavior 31(June):173-184.

Bachman, Jerald G., J. M. Wallace, Jr., P. M. O'Malley, L. D. Johnston, C. L. Kurth, and H. W. Neighbors. 1991. "Racial/Ethnic Differences in Smoking, Drinking, and Illicit Drug Use among American High School Seniors, 1976-89, American Journal of Public Health 81(3):372-377.

Biderman, Albert D. and J. P. Lynch. 1991. Understanding Crime Incidence Statistics. Why the UCR Diverges From the NCS. New York, NY: SpringerVerlag.

Black Donald J. 1970. "The Production of Crime Rates," American Sociological Review 35:733-748.

Black, Donald J. and A. J. Reiss, Jr. 1970. "Police Control of Juveniles," American Sociological Review 35:63-77.

Block, Carolyn R. and R. L. Block. 1984. "Crime Definition, Crime Measurement, and Victim Surveys," Journal of Social Issues 40:137-160.

Block, Richard L. 1974. "Why Notify the Police," Criminology 11:555-569.

Blumstein, Alfred, Cohen, J. and R. Rosenfeld. 1991. "Trend and Deviation in Crime Rates: A Comparison of the UCR and NCS Data for Burglary and Robbery," Criminology 29:237-263. 
Blumstein, Alfred, Cohen, J. and R. Rosenfeld. 1992. "The UCR-NCS Relationship Revisited: A Reply to Menard, Criminology 30:115-124.

Bureau of the Census. 1971-1993. Statistical Abstract of the United States, 19701992. Washington, DC: U.S. Department of Commerce, Bureau of the Census.

Bureau of Justice Statistics. 1992a. Criminal Victimization 1991. Washington, DC. U.S. Department of Justice.

Bureau of Justice Statistics. 1975b-1992b; 1992c. Criminal Victimization in the United States 1979-1991. Washington, DC: U.S. Department of Justice.

Bureau of Justice Statistics. 1989c. Felony Sentences in State Courts, 1986. Washington, DC: U.S. Department of Justice.

Bureau of Justice Statistics. 1990c. Felony Sentences in State Courts, 1988. Washington, DC: U.S. Department of Justice.

Bureau of Justice Statistics. 1992d. National Corrections Reporting Program, 1988. Washington, DC: U.S. Department of Justice.

Bureau of Justice Statistics. 1990d. National Corrections Reporting Program, 1985. Washington, DC: U.S. Department of Justice.

Bureau of Justice Statistics. 1971e-1992e. Sourcebook of Criminal Justice Statistics 1970-1991. Washington, DC: U.S. Department of Justice.

Chambliss, William J. 1984. "Crime Rates and Crime Myths." Pp. 167-177 in W. J. Chambliss (ed.), Criminal Law in Action. New York, NY: John Wiley. Clark, K. B. 1965. Dark Ghetto: Dilemmas of Social Power. New York: Harper and Row. 
Federal Bureau of Investigation. 1971-1992. Crime in the United States: Uniform Crime Reports 19r0-1991. Washington, DC: U.S. Department of Justice, The Federal Bureau of Investigation.

Freeman, Richard B. 1992. "Understanding Crime, Gangs, and Neighborhoods: Ethnographic Research and Social Science Analysis." In J. Fagan (ed.), The Ecology of Crime and Drug Use in American Inner Cities: Social Structure and Neighborhood Dynamics, forthcoming.

Freeman, Richard B. 1991. "Crime and the Economic Status of Disadvantaged Young Men," Paper presented at the Conference on Urban Labor Markets and Labor Mobility, Airlie House, VA, March 7, 1991.

Grogger, Jeff. 1992. "Criminal Opportunities, Criminal Activity, and Young Men's Labor Supply." Working Paper, Department of Economics, University of California, Santa Barbara, CA.

HARYOU. 1964. Youth in the Ghetto: A Study of the Consequences of Powerlessness and a Blueprint for Change. New York: Harlem Youth Opportunities Unlimited.

Huff, C. Ronald (ed.). 1990. Gangs in America. Newbury Park, CA: Sage Publications.

Jencks, Christopher. 1991. "Is the American Underclass Growing?" Pp. 28-100 in Christopher Jencks and Paul E. Peterson (eds.), The Urban Underclass. Washington, DC: The Brookings.Institution.

Kandel, Denise B. 1991. "The Social Demography of Drug Use," The Milbank Quarterly 69(3):365-414.

Kornblum, William. 1991. "Drug Legalization and the Minority Poor," The Milbank Quarterly 69(3):415-435.

Lamar, Jacob V. 1986. "Crack," Time 127:16-18. 
Langan, Patrick A. 1991. "America's Soaring Prison Population," Science 251:15681573.

Levine, James P. 1976. "The Potential for Crime Overreporting in Criminal Victimization Surveys," Criminology 14:307-330.

McDowall, David and Colin Loftin. 1992. "Comparing the UCR and NCS Over Time, ${ }^{n}$ Criminology 30:125-132.

Morganthau, Tom, Greenberg, N. F., Murr, A., Miller, M., and G. Raine. 1986. "Crack and Cocaine," Newsweek 107:16-22.

National Center for Health Statistics. 1977-1991. Vital Statistics of the United States, 1979-1988, Vol. 2, Mortality, Part A. Public Health Service, Washington, DC: U.S. Government Printing Office.

National Institute on Drug Abuse. 1982-1991a. Annual Data 19-: Data From the Drug Abuse Warning Network, 1981-1990. Washington, DC: U.S. Department of Health and Human Services.

National Institute on Drug Abuse. 1991b. Drug Use Among American High School Seniors, College Students, and Young Adults, 1975-1990, Vol. 1: High School Seniors. Washington, DC: U.S. Department of Health and Human Services.

National Institute on Drug Abuse. 1991c. Drug Use Among American High School Seniors, College Students, and Young Adults, 1975-1990, Vol. 2: College Students and Young Adults. Washington, DC: U.S. Department of Health and Human Services.

National Institute on Drug Abuse. 1991d. National Household Survey on Drug Abuse: Highlights 1990. Washington, DC: U.S. Department of Health and Human Services. 
National Institute on Drug Abuse. 1991e. National Household Survey on Drug Abuse: Main Findings 1990. Washington, DC: U.S. Department of Health and Human Services.

O'Brien, Robert M. 1985. Crime and Victimization Data: Volume 4, Law and Criminal Justice Series. Beverly Hills, CA: SAGE Publications.

Skogan, Wesley G. (ed.). 1976. Sample Surveys of Victims of Crime. Cambridge, MA: Ballinger.

Sullivan, Mercer. 1989. Getting Paid: Youth Crime and Work in the Inner City. New York: Cornell University Press.

Turner, Anthony G. 1972. The San Jose Methods Test of Known Crime Victims. National Criminal Justice Information and Statistics Service, Law Enforcement Assistance Administration. Washington, DC: U.S. Government Printing Office.

U.S. Bureau of the Census. 1993. Current Population Reports, P25-1095, U.S. Population Estimates by Age, Sex, Race, and Hispanic Origin: 1980 to 1991. Washington, D.C.: U.S. Government Printing Office.

Williams, T. 1989. The Cocaine Kids. Reading, Mass.: Addison Wesley.

Wilson, William Julius. 1987. The Truly Disadvantaged: The Inner City, the Underclass, and Public Policy. Chicago, IL: University of Chicago Press. 
TABLE 1: INCARCERATION RATE DECOMPOSITION 1974-1979

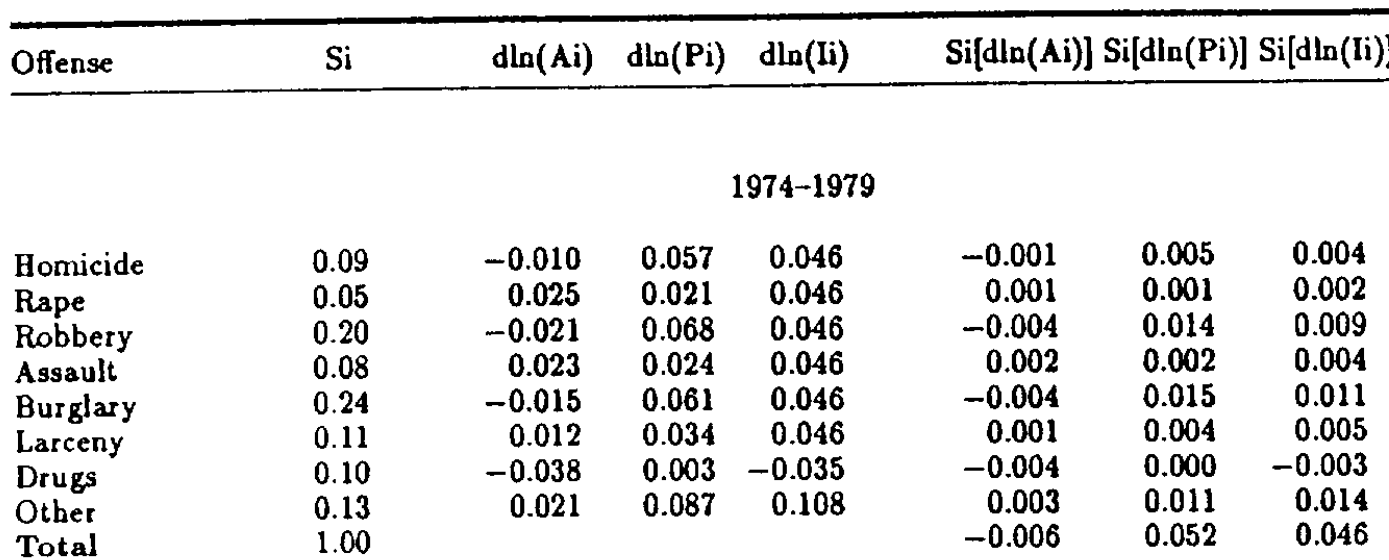

\begin{tabular}{lrrrrrrr} 
& \multicolumn{7}{c}{$1979-1988$} \\
Homicide & 0.07 & 0.001 & 0.022 & 0.023 & 0.000 & 0.002 & 0.002 \\
Rape & 0.06 & 0.016 & 0.092 & 0.108 & 0.001 & 0.005 & 0.006 \\
Robbery & 0.16 & -0.003 & 0.025 & 0.022 & -0.001 & 0.004 & 0.003 \\
Assault & 0.08 & 0.036 & 0.037 & 0.073 & 0.003 & 0.003 & 0.005 \\
Burglary & 0.21 & -0.019 & 0.075 & 0.056 & -0.004 & 0.016 & 0.012 \\
Larceny & 0.12 & 0.022 & 0.075 & 0.098 & 0.003 & 0.009 & 0.011 \\
Drugs & 0.17 & 0.071 & 0.143 & 0.215 & 0.012 & 0.024 & 0.035 \\
Other & 0.16 & 0.023 & 0.073 & 0.095 & 0.003 & 0.011 & 0.015 \\
Total & 1.00 & & & & 0.017 & 0.074 & 0.089
\end{tabular}

\begin{tabular}{llrlllll} 
Homicide & 0.07 & -0.003 & 0.034 & 0.031 & 0.000 & 0.002 & 0.002 \\
Rape & 0.06 & 0.019 & 0.067 & 0.086 & 0.001 & 0.004 & 0.005 \\
Robbery & 0.16 & -0.010 & 0.040 & 0.030 & -0.002 & 0.006 & 0.005 \\
Assault & 0.08 & 0.031 & 0.032 & 0.064 & 0.002 & 0.002 & 0.005 \\
Burglary & 0.21 & -0.017 & 0.070 & 0.053 & -0.004 & 0.015 & 0.013 \\
Larceny & 0.12 & 0.019 & 0.061 & 0.079 & 0.002 & 0.007 & 0.009 \\
Drugs & 0.19 & 0.032 & 0.093 & 0.126 & 0.006 & 0.017 & 0.023 \\
Other & 0.14 & 0.022 & 0.078 & 0.100 & 0.003 & 0.011 & 0.013 \\
Total & 1.00 & & & & 0.008 & 0.064 & 0.073 \\
\hline
\end{tabular}

Source: Langan, Patrick. "America's Soaring Prison Population." Science 251:1568-1573.

National Corrections Reporting Program, 1988. Statistical Abstract of the U.S., various years. 
TABLE 2: RECENT ESTIMATES OF THE LEVEL OF CRMINAL ACTIVITY AND DRUG USE

\begin{tabular}{lcc}
\hline & White & Black \\
\hline & & \\
Violent Crime Victimization Rate, 1990 & 28.2 & 39.7 \\
Violent Crime Victizimation Rate 20-24, 1990 & 64.7 & 64.7 \\
Violent Crime Victizimation Rate Male 20-24, 1990 & 79.9 & 82.0 \\
Personal Theft Victimization Rate, 1990 & 63.6 & 64.0 \\
Personal Theft Victimization Rate 20-24, 1990 & 111.2 & 116.8 \\
Murder Rate, 1990 & 0.05 & 0.32 \\
Murder Rate 20-24, 1990 & 0.10 & 0.71 \\
Murder Arrest Rate, 1990 & 0.04 & 0.33 \\
Violent Crime Arrest Rate, 1990 & 1.42 & 7.89 \\
Motor Vebicle Theft Arrest Rate, 1990 & 0.50 & 2.15 \\
Drug Arrest Rate, 1990 & 2.52 & 11.67 \\
Total Arrest Rate for Index Crimes and Drug Crimes, 1990 & 9.74 & 37.62 \\
Murder Incarceration Rate, 1988 & & \\
Violent Crime Incarceration Rate, 1988 & 0.01 & 0.10 \\
Motor Vehicle Theft Incarceration Rate, 1988 & 0.07 & 0.80 \\
Drug Offense Incarceration Rate, 1988 & 0.01 & 0.08 \\
Total Incarceration Rate for Index Crimes and Drug Crimes, 1988 & 0.09 & 0.89 \\
Estimated ER Cocaine Admission Rate, 1990 & 0.32 & 2.65 \\
Estimated ER Cocaine Admission Rate 20-29, 1990 & & \\
Total Cocaine Death Rate, 1988 & 0.12 & 1.43 \\
\hline
\end{tabular}

-Excluding forcible rape.

Notes: Victimization Rales are per 1,00012 and over.

Arrest Rates, Death Rates, Incarceration Rates, and ER Admission Rates are per 1,000 resident population.

Source: Statistical Abstract of the U.S., Crime in the U.S., Criminal Victimization in the U.S.,

Vital Statistics of the U.S., various years. Annual Dats 1990: Data from the Drug Abuse Warning Network. 


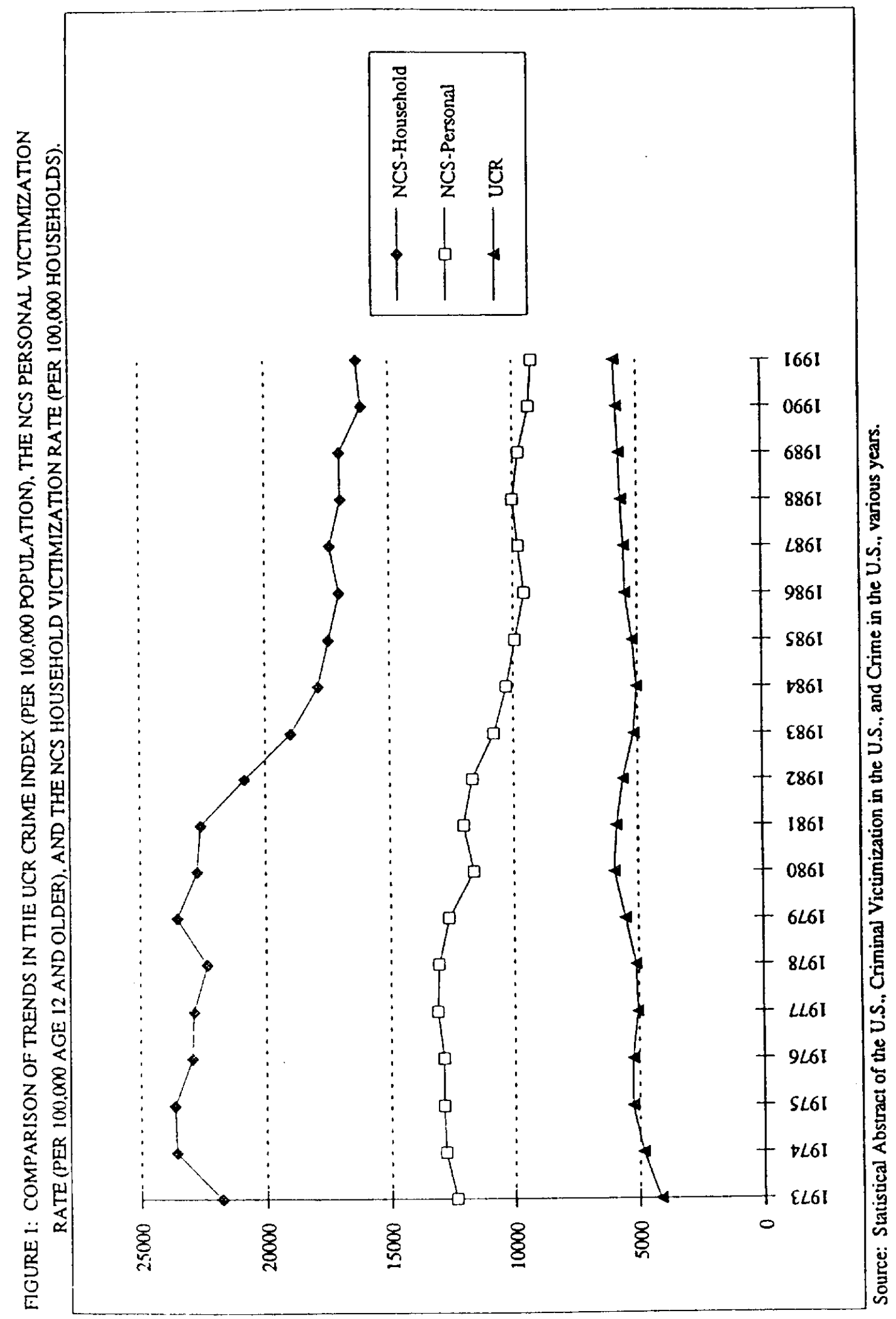




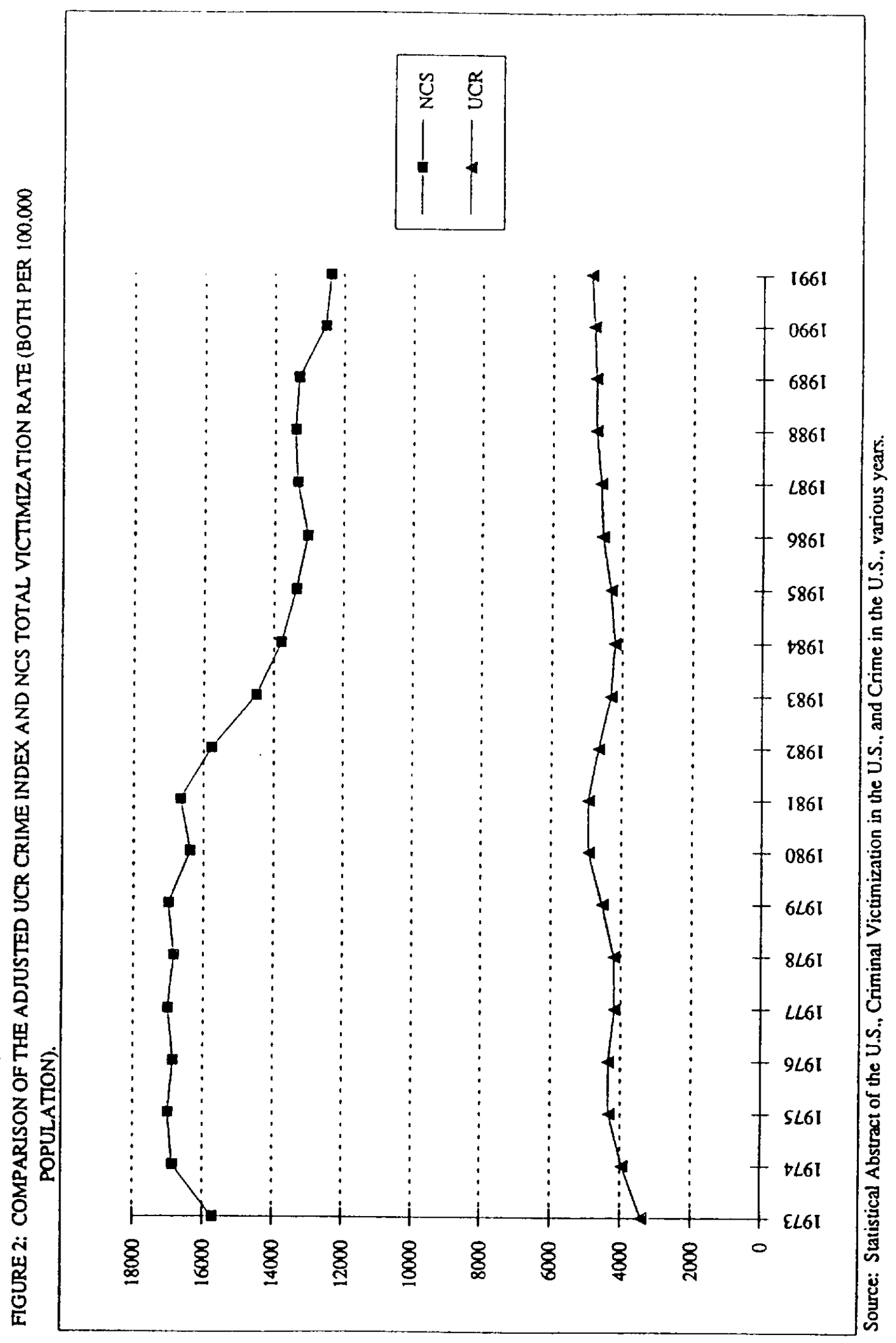


FILURE 3: CONGARLSON OF UCR CKUML: KATRS ANU NIS VCTIAUZAIION RATES FOR VANJOUS OFFENSES. 1973-1991 (RATE MER IOOOXORESIDINT POPULATON
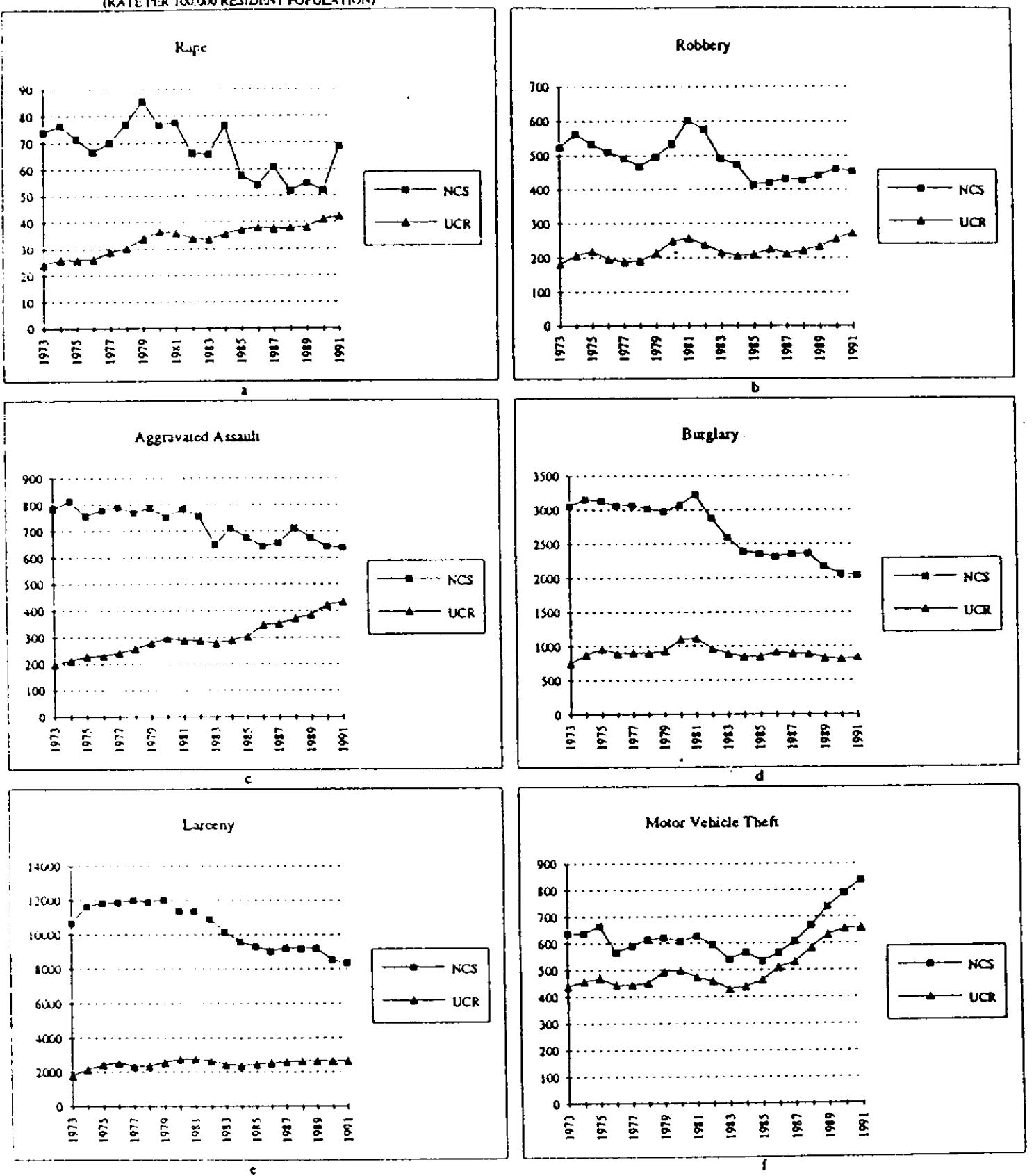

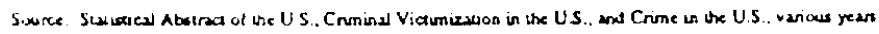


FIGURE 4: ESTIMIATED VICTIMIIZATION RATES BY RACE OF VICTIM. $1973-1991$.
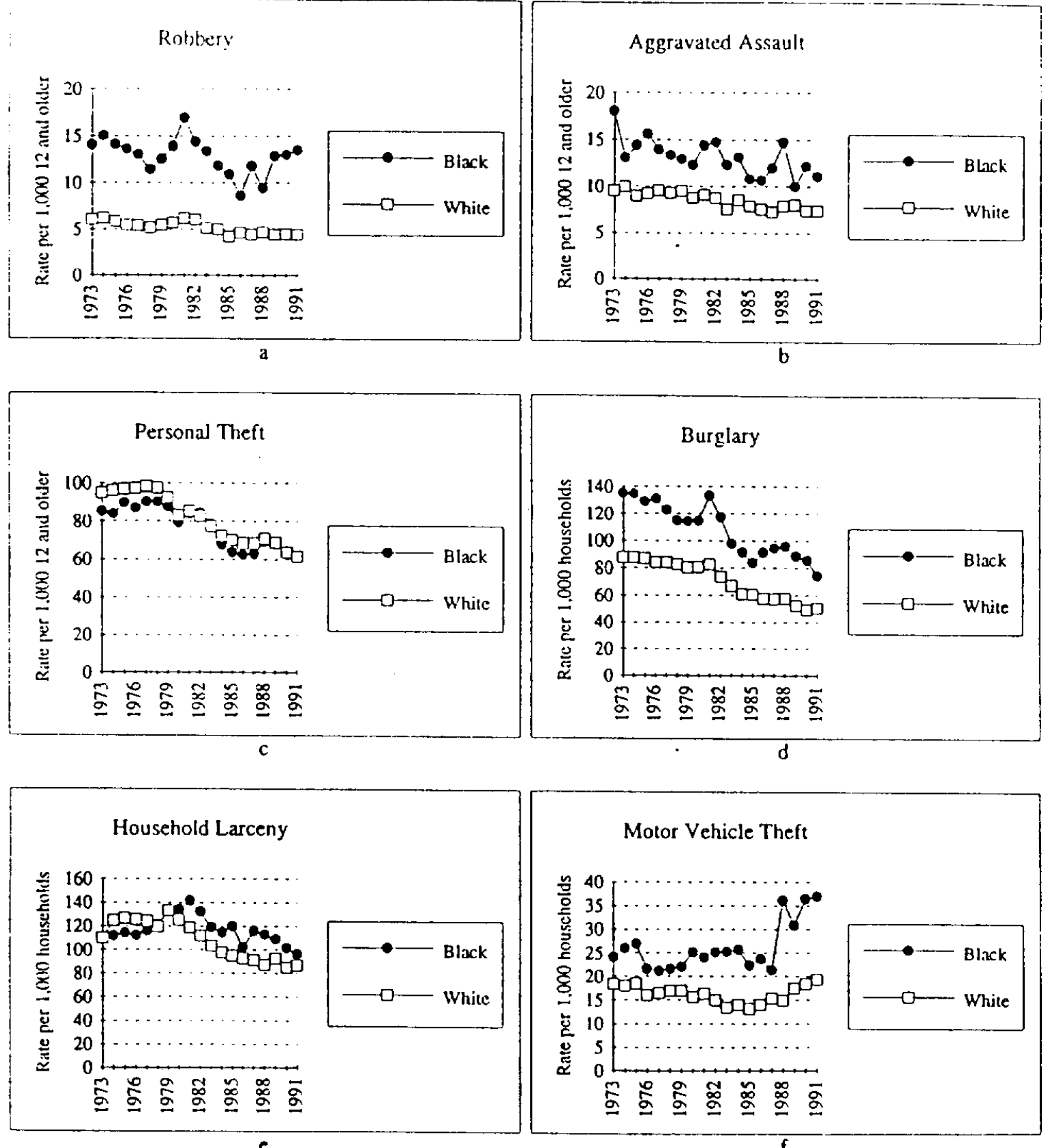

Source: Current Population Reports, P25-1095: Statistical Abstract of the U.S. and Criminal Victumization in the U.S., various years. 


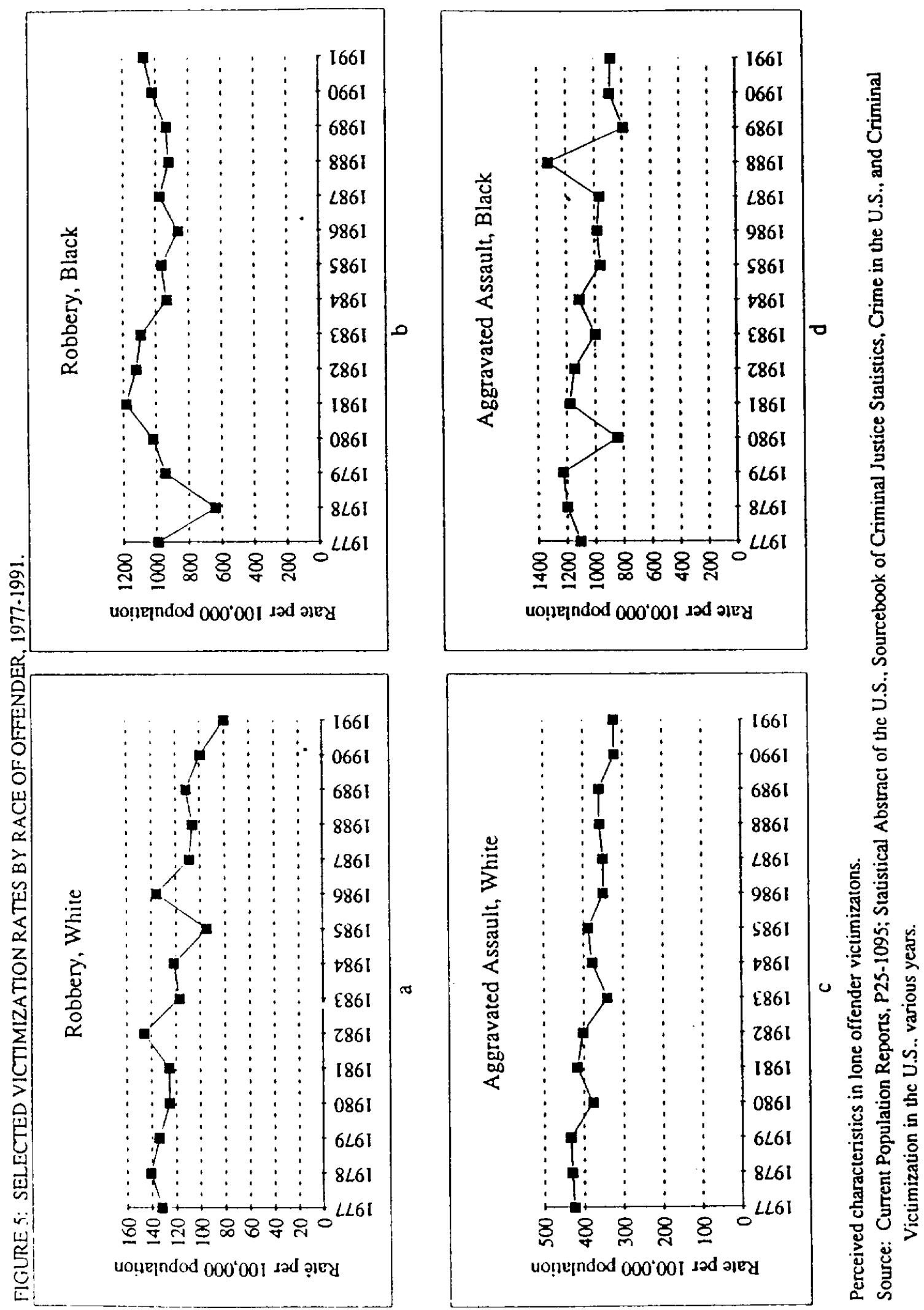




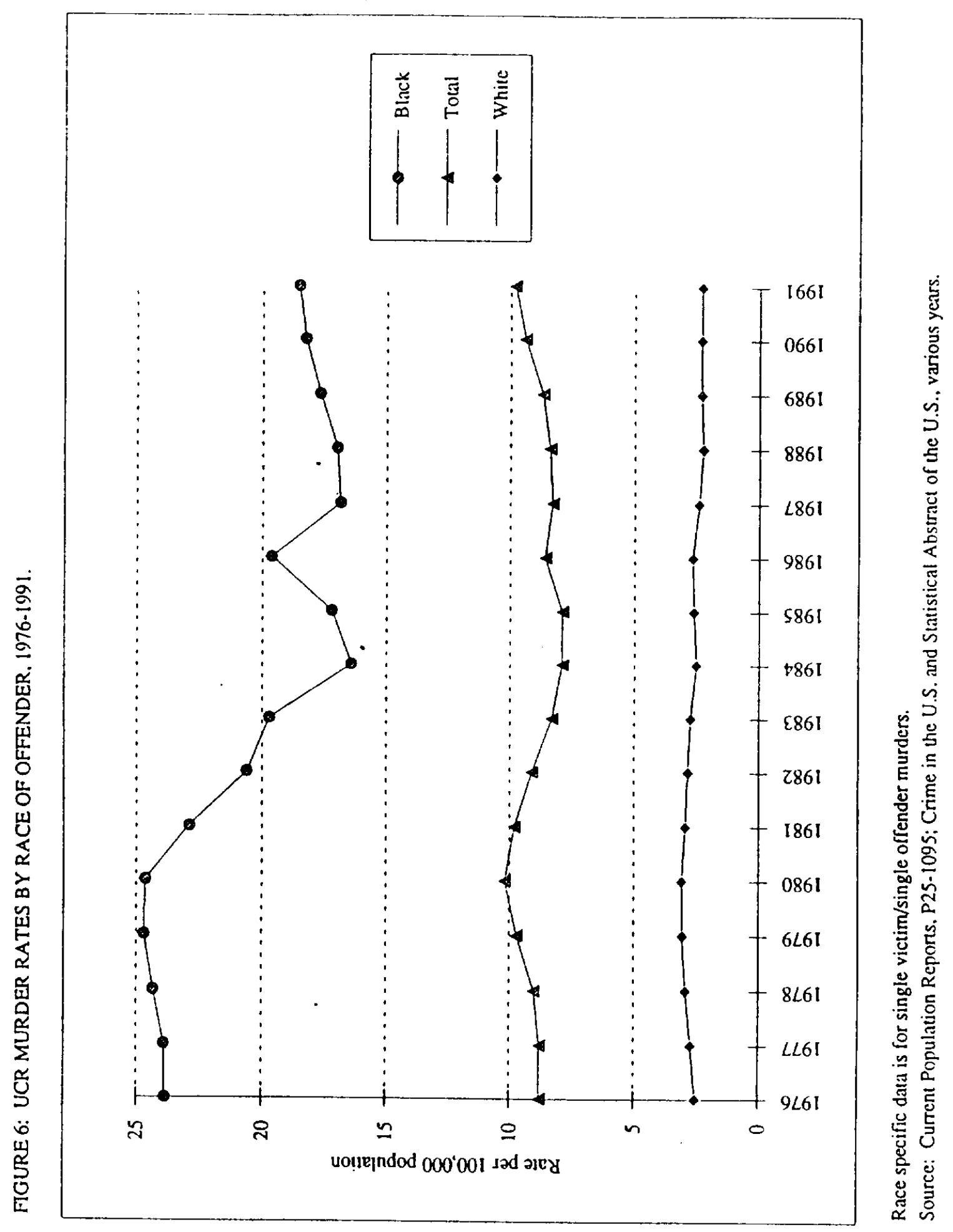


White

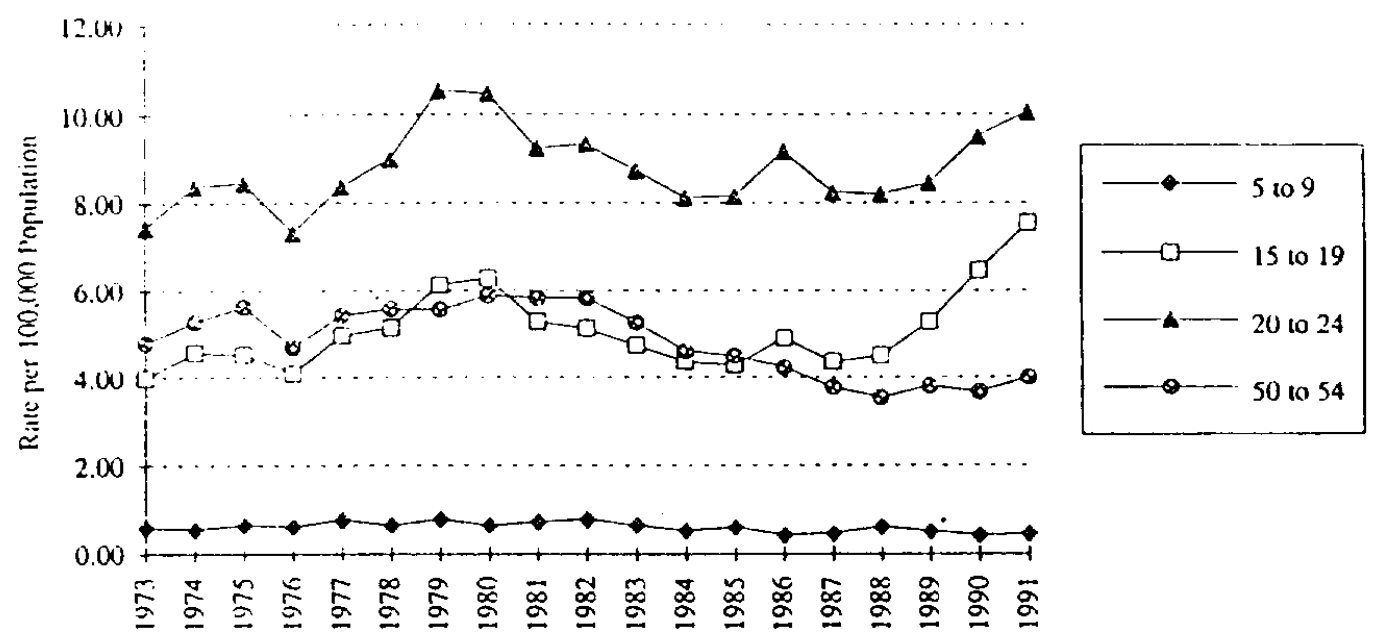

Black

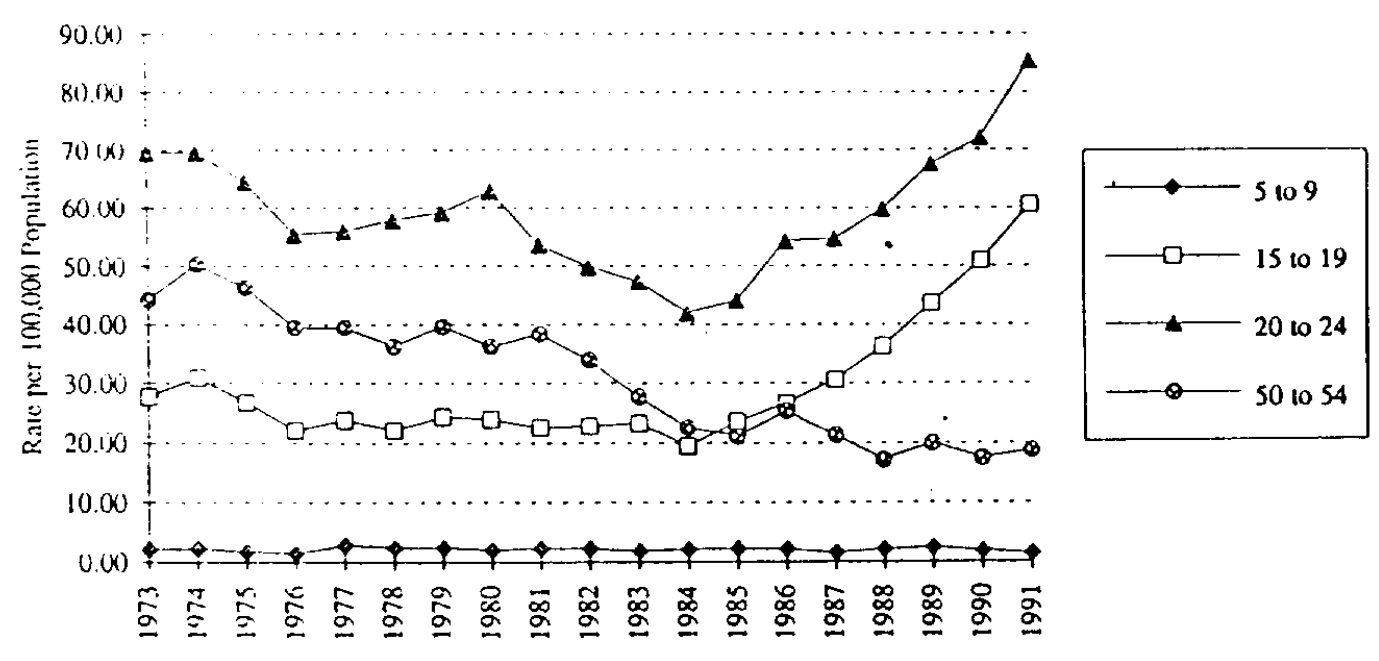

Sultce: Current Poputation Repons, P25-1095; Crime in ule U.S. and Statisticat Abstract of the U.S., various years. 


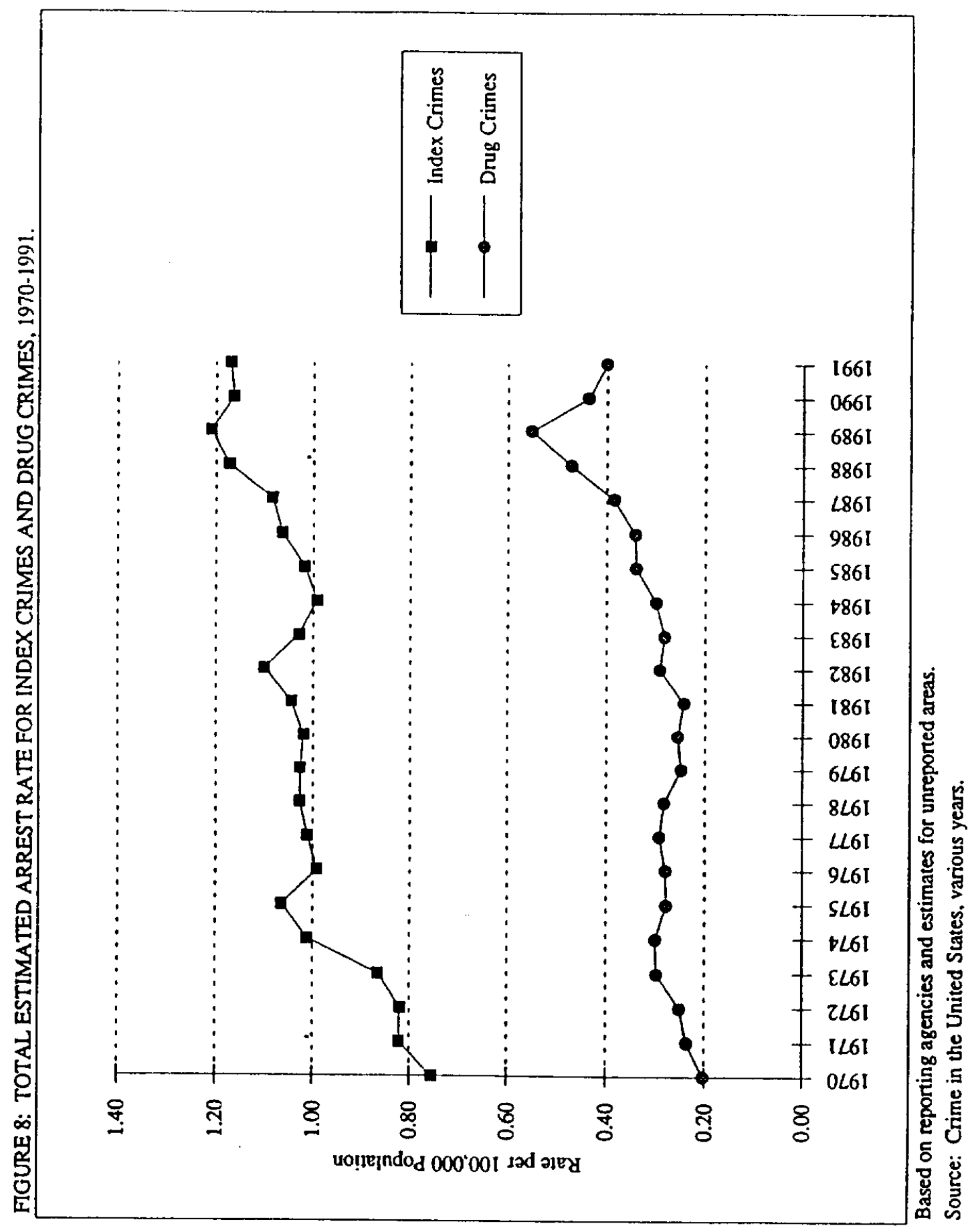


FIGURE 9: REYORTED RECENCY OF COCAINE USE AMONG HIGH SCHOOL SENIORS, COLLEGE STUDENTS. AND YOUNG ADULTS, 1975-1991.

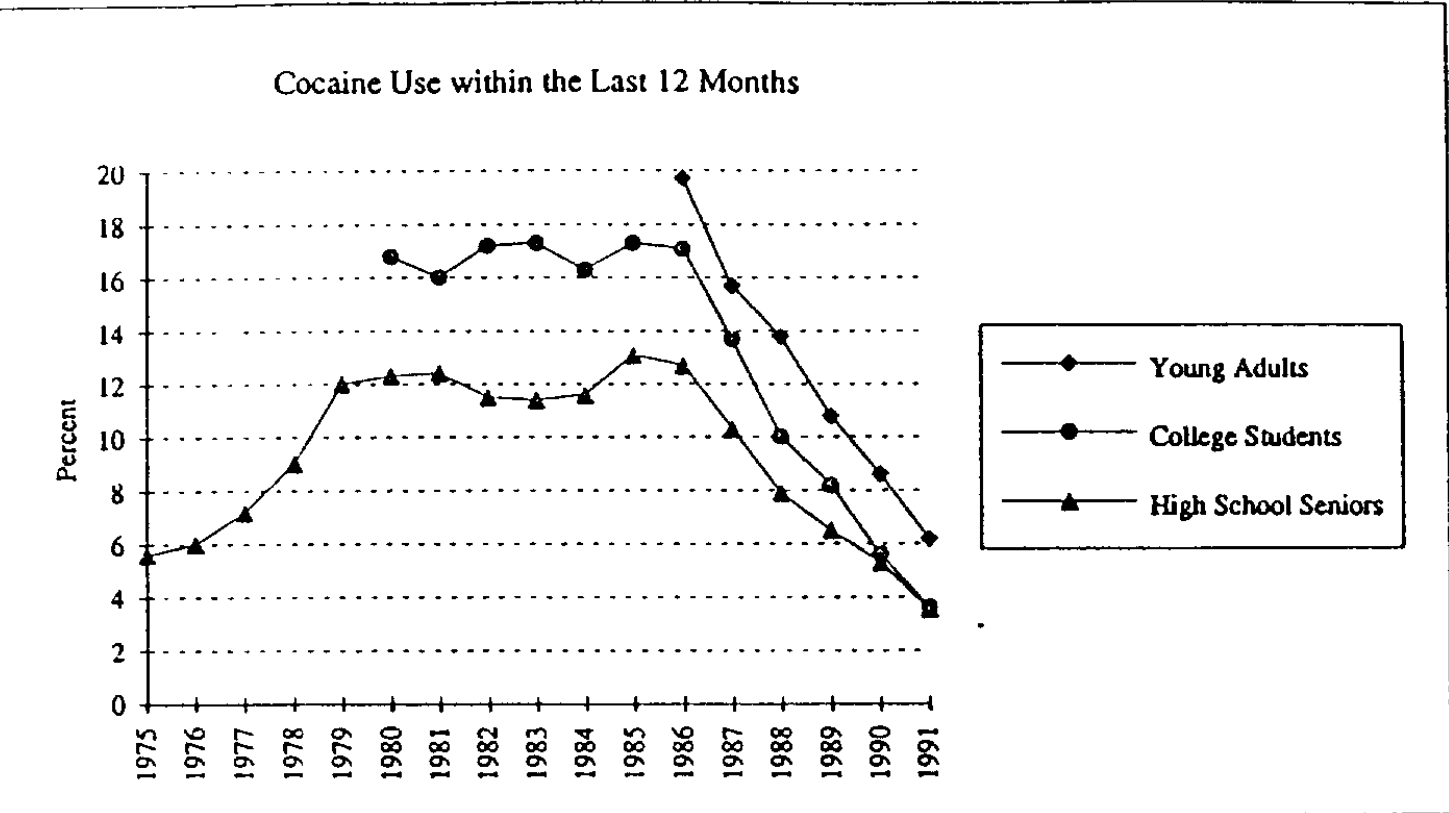

a

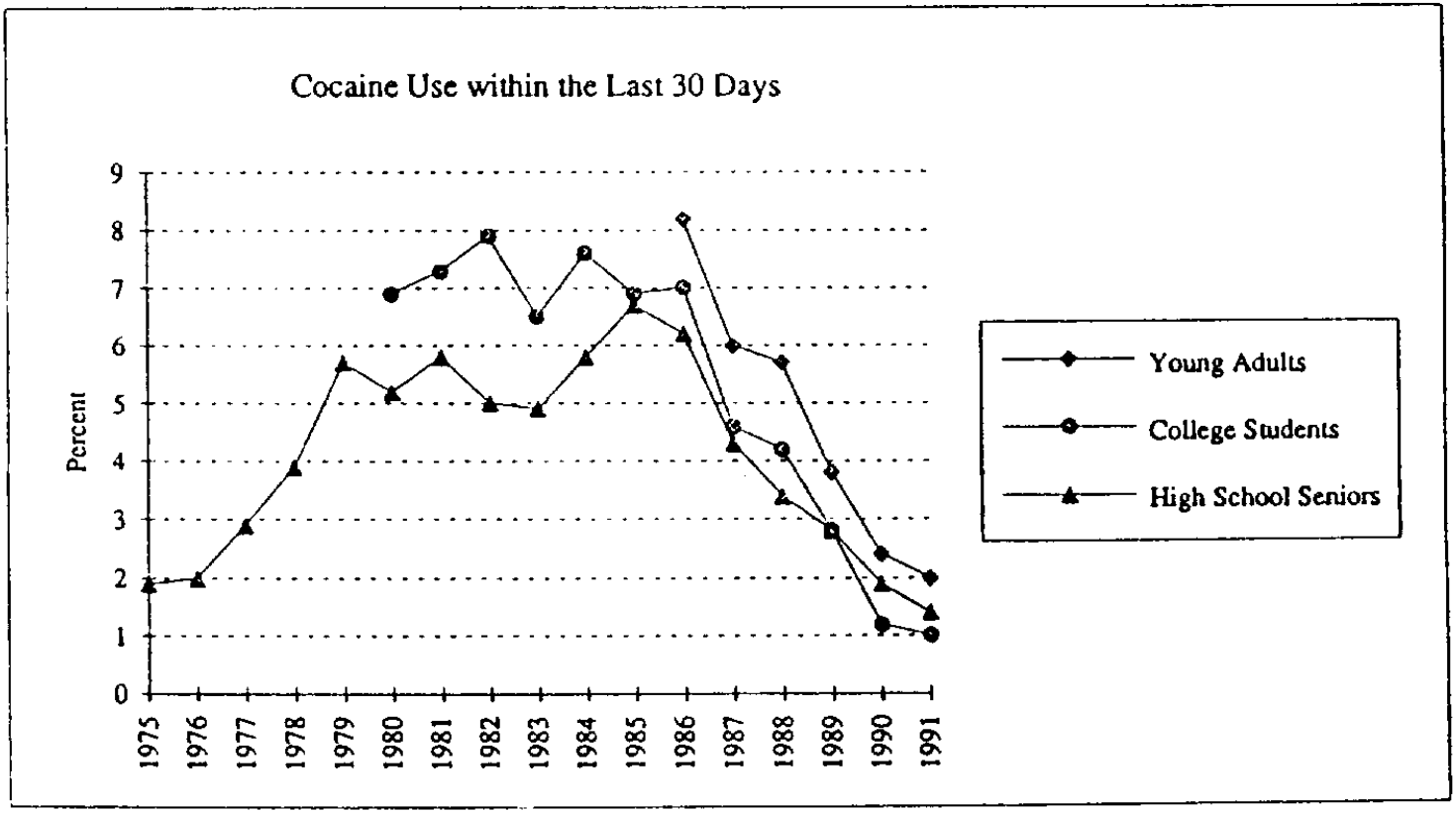

b

Source: Sourcebook of Criminal Justice Statistics, 1991. Drug Use Among American High School Seniors, College Srudents. and Young Adults, 1975-1990, Vols. 1 and 2. 


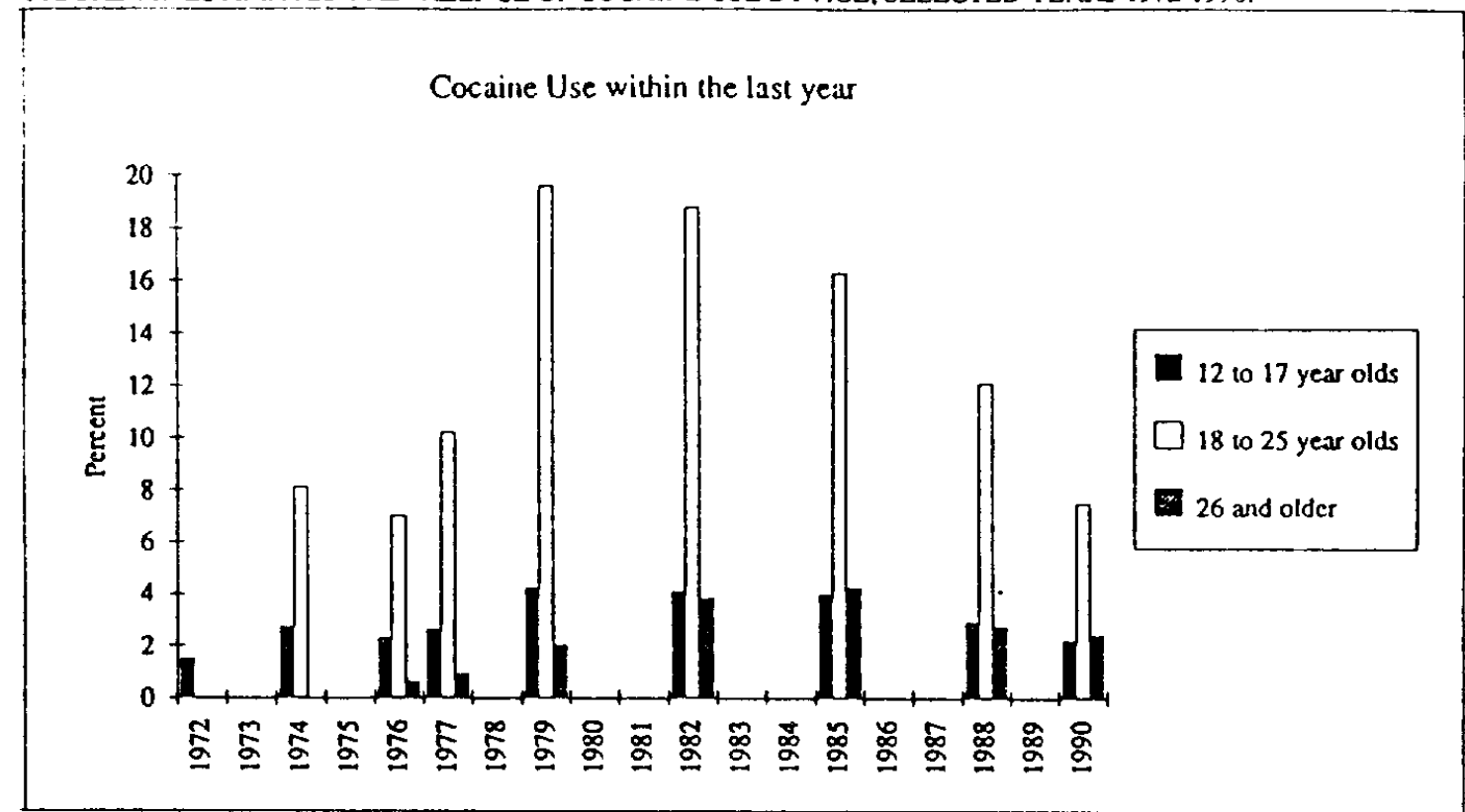

a

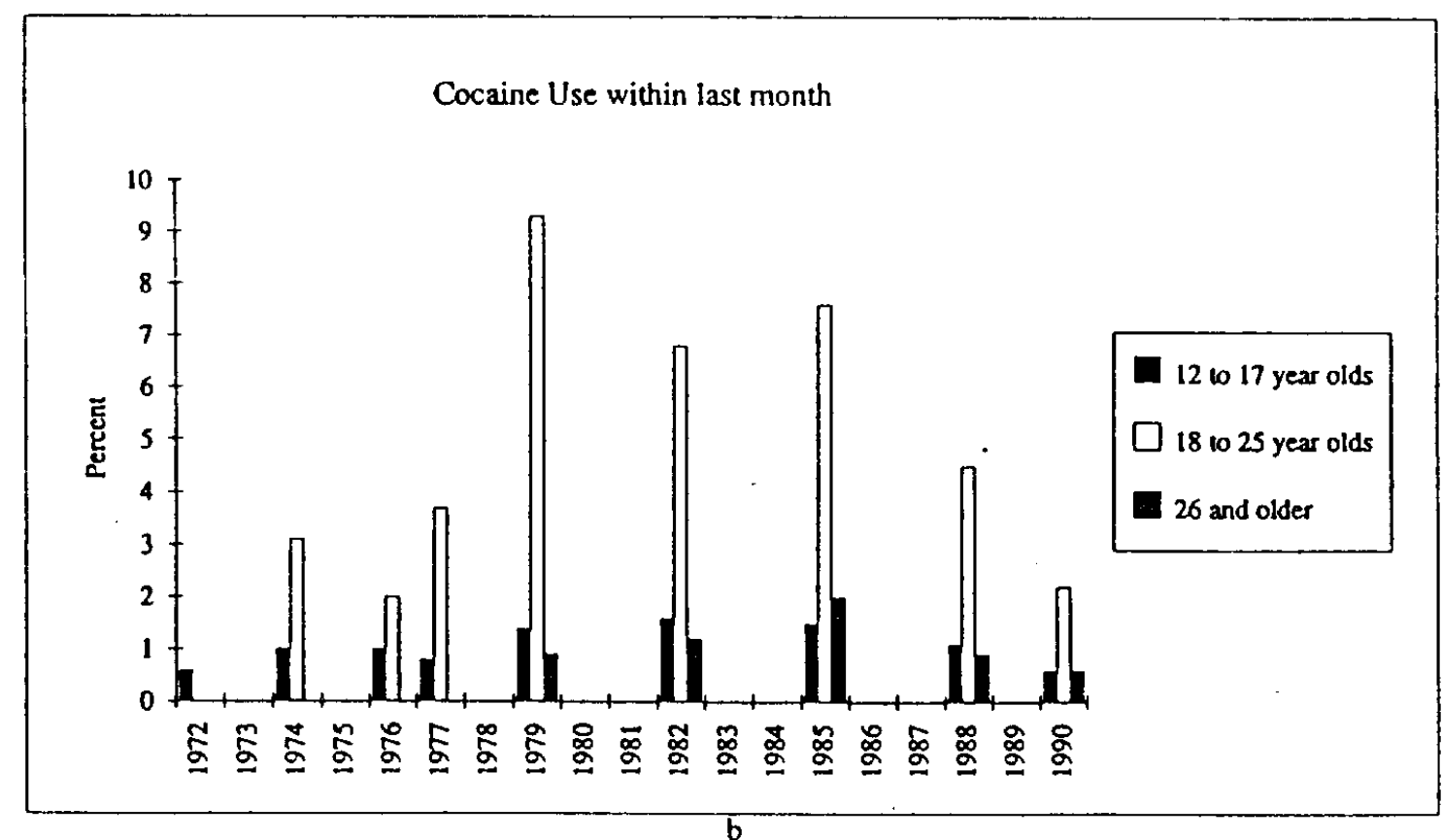

Source: National Household Survey on Drug Abuse: Main Findings 1990. Sourcebook of Criminal Justice Statistics, 1991. 


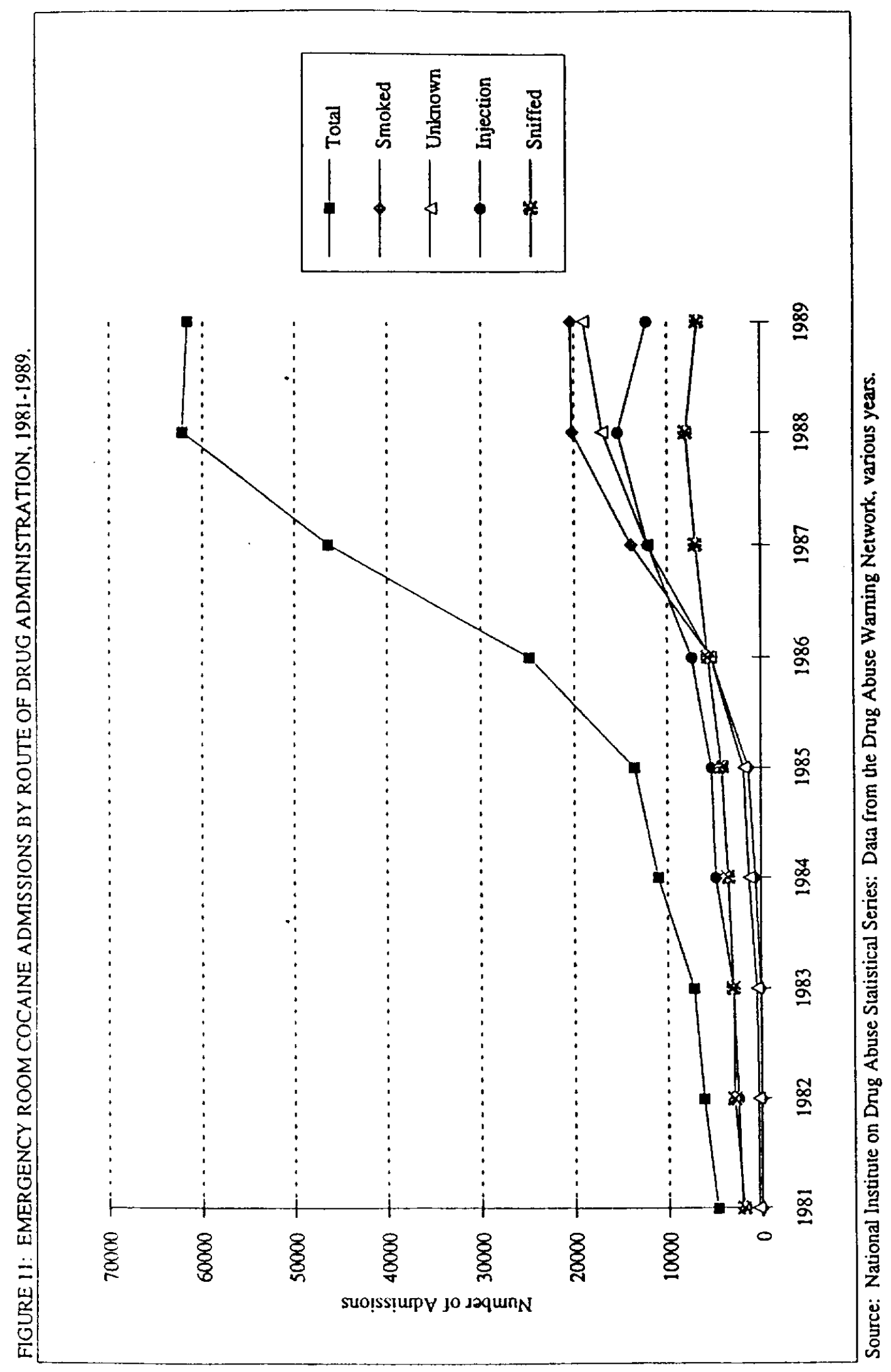




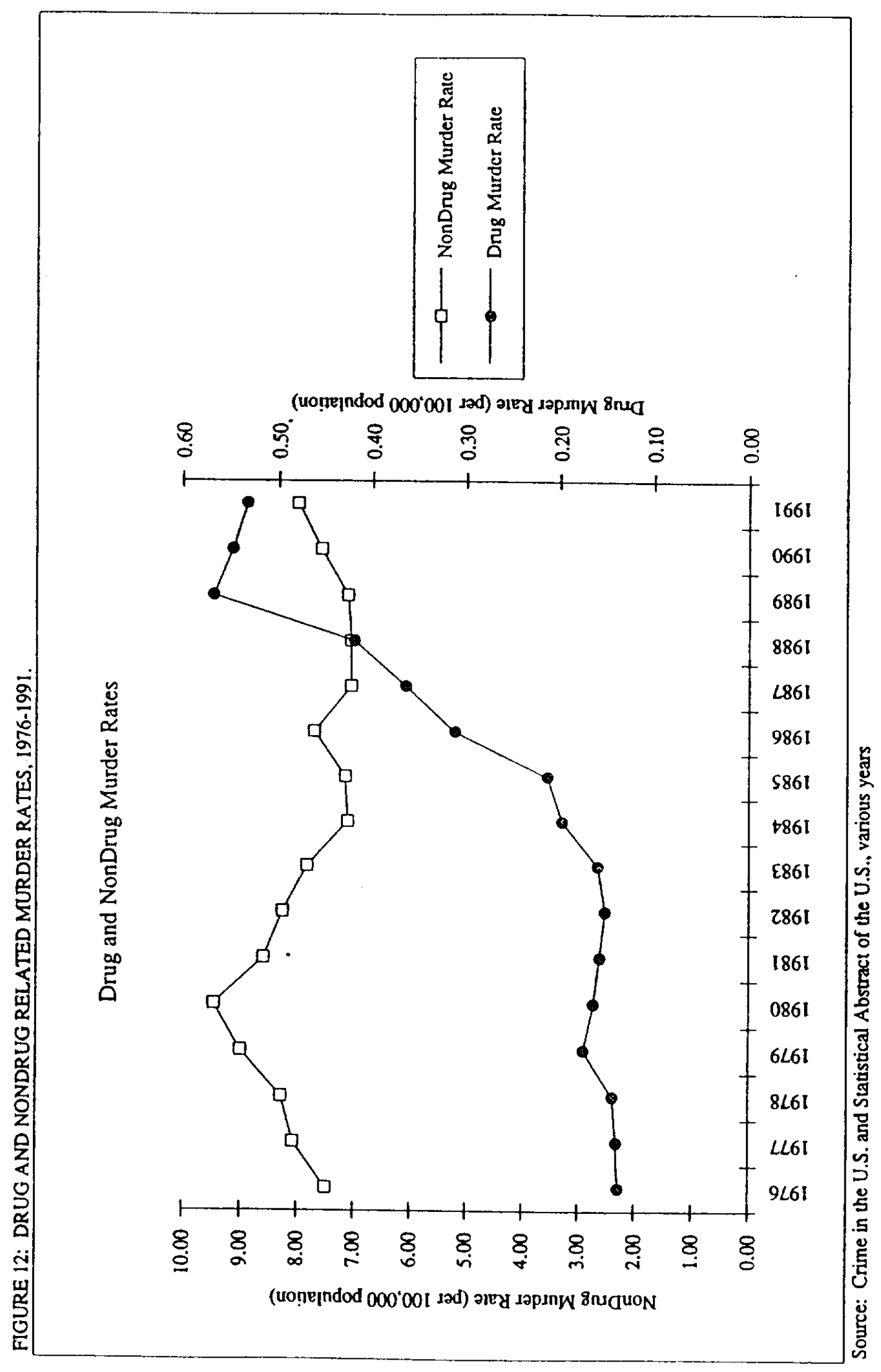

